\title{
The Sustainable Design and Renewal of Water's Edge Public Spaces in the Asia-Pacific Region: Sydney, Hong Kong and Singapore
}

\author{
Mabel John ${ }^{1}$, Steffen Lehmann ${ }^{1} \&$ Alpana Sivam ${ }^{2}$ \\ ${ }^{1}$ Zero Waste Centre for Sustainable Design \& Behaviour (sd+b Centre), School of Art, Architecture and Design, \\ University of South Australia, Australia \\ ${ }^{2}$ School of Natural and Built Environments, University of South Australia, Australia \\ Correspondence: Mabel John, Zero Waste Centre for Sustainable Design \& Behaviour, City West Campus, \\ University of South Australia, GPO Box 2471, Adelaide, SA 5001, Australia. Tel: 61-406-672-534. E-mail: \\ Mabel.John@unisa.edu.au
}

Received: December 13, 2012 Accepted: June 24, 2013 Online Published: July 16, 2013

doi:10.5539/jsd.v6n8p26 URL: http://dx.doi.org/10.5539/jsd.v6n8p26

\begin{abstract}
Emerging water's edge public spaces display distinct characteristic features and stand apart from historic ones. In analysing these emerging spaces it becomes clear that there has been a shift towards enhancing environmental connections while: 1) encouraging mixed use functionality; 2) focusing on heritage preservation and adaptive re-use; 3) applying green urbanism principles; 4) implementing technological connectivity, maintaining and establishing connections to urban networks; 5) allowing avenues of incomplete urbanism; and 6) harnessing renewable energies in the public domain. Water's edge developments are not only significant locally but are a key to the identity and perceived image of the selected cities. The rediscovery of the image of a city and economic benefits of tourism are the drivers of the development of any city's waterfront or riverfront. This paper presents the outcomes of a pilot study that compared three water's edge public spaces in Asia-Pacific cities at different stages of their lifecycles. It analyses and discusses factors in the sustainable design and renewal of such spaces. The aim of the overall study, that this paper is the first part of, is the consideration of sustainability and models of sustainability evaluation in a comparative urbanism framework for Water's Edge Public Spaces.

This research suggests that architectural science input should be increased during the initial stages of design, to ensure continual links with biological and seasonal cycles, including other environmental processes over time. Results are presented within the context of changing relationship dynamics, understanding underlying subservient associations established due to colonisation, with a deep-seated realisation of the valued and reliant social, architectural and cultural relationships between the East and the West.
\end{abstract}

Keywords: water's edge, sustainable design, green urbanism, emerging public spaces, convergence and divergence, architectural science

\section{Introduction}

Some well developed and emerging relationships between cities can be analysed by understanding the city's association with water. We can differentiate city typologies based on their historic and current connections with water, such as cities on a river, harbour, bay, estuary, delta or ocean shore. Many cities have originated near or on the edge of water bodies, because water is essential in terms of sustaining life, having historically enabled trade and commerce, and, today water is still an essential part of cities and their transformative development. The sustainable design of water's edge public spaces is an integral part of the realisation of the cities of tomorrow. Historically, trading posts and routes have facilitated cultural exchange and interaction at levels surpassing other spaces. Areas alongside harbours and docking points have been fertile ground for the display of commercial, social, architectural and cultural hierarchies. These dynamics are continually changing and, as populations and economic relationships alter over time, the physical manifestations remain visible in the architecture, buildings, structures and, most prominently, the design of public spaces.

In association with physical manifestations, virtual aspects (i.e. online versions of reality, animated connections, gaming strategies, virtual landscapes and technological reminders) allow us to understand and appreciate changing architectural forms. Public spaces are constantly evolving due to people's thoughts, views, interests 
and use of them. The nature of associated private space is also changing, from primarily retail and commercial to mixed use, recreational and technological. This shift is occurring as consumers move to customised online purchasing, away from traditional shopping methods. Privately-owned spaces on the water's edge are slowly being transformed by city-defining buildings including casinos, hotels, restaurants and bars. Increasingly, shopping interfaces remain, but shop owners struggle to be competitive with specialised online, bulk, or chain retailers, who do not bear similar profit to rental expense ratios.

Three global cities from the Asia-Pacific region, i.e. Sydney, Hong Kong and Singapore, have been analysed using a comparative urbanism framework as part of the pilot study presented in this paper. The case studies chosen are within these three cities, the cities themselves have a shared heritage as British colonies: all of them were influenced by the British, to varying degrees, and with varying effects due to their individual experience of colonisation, and each developed differently over time. Most water's edge public space designs do not currently incorporate biological and environmental aspects (including the understanding of changing processes and cycles) This paper investigates whether new and upgraded water's edge public spaces should consider the key links between architectural design and architectural science (especially considering the environment and biology through time). The flow of energy within water's edge public spaces is considered crucial in understanding the variables and parameters that drive change.

In critically analysing emerging public spaces, it has become clear that a comparative analysis to study these water's edge public spaces is lacking. This critical analysis is however not the focus of this paper.

The outcomes of the pilot study lead to preliminary recommendations and the development of conceptual models to aid the sustainable design of water's edge public spaces.

This paper excludes public spaces that are not on a water's edge, even if they are 'restive' or 'restorative', and focuses upon "convivial" water's edge public spaces (as defined by Shaftoe, 2008; Banerjee, 2001; Peattie, 1998). Waterfronts and riverfronts may be used for recreational purposes where densities are lower, with walking, running and outdoor fitness contributing towards urban health and wellbeing. Overall, public spaces (especially water's edge public spaces) are important because, amongst other things, they play a key role in encouraging physical activity, particularly walking and cycling for transport or recreation (Giles-Corti, 2006), and in increasing positive and/or chance social interactions and social trust (Karuppannan \& Sivam, 2011), thereby aiding individuals' personal endeavours to maintain healthy bodies and minds, while also promoting community cohesion.

\section{Background}

Water's edge public spaces are convivial spaces, being major transportation hubs, destinations, historic ports, developed waterfronts or riverfronts, or promenades. These spaces were previously used for port trade and water-based transportation, and are currently used for lifestyle, cultural, environmental and innovative pursuits. The pilot study has analysed architectural science models for the sustainable design of water's edge public spaces. The water's edge public spaces analysed are at different stages of their lifecycles.

\subsection{The Individual in a Water's Edge Public Space}

To understand the individual in a water's edge public space we need to cosider: a) connections, b) interaction and c) reliance, we must go back to the most basic single entity, namely an individual's 'self' and its reliance on nature.

The connection an individual makes with his/her environment is intrinsic to their environment, and as the world's population becomes more urbanised, an individual's perceived connections with natural environmental elements diminish. Perceptions of nature become limited to immediate experience, that is, open spaces, parks, reserves and existing water's edges. Staggeringly few of the natural formations that cities were historically created around (for example, hills, valleys and riversides) remain in their original state. The reality of our daily dependence on nature for food, shelter and oxygen becomes further removed from our consciousness and is often taken for granted due to commoditisation and corporatisation changing our lifestyles. For example, purchasing apples from a supermarket becomes more common than picking apples from a tree. This growing disconnect between the self and the environment drives fluctuations of public and corporate environmentalism, including green thinking philosophies, to-and-fro, away and back into our radars over time (from Ebenezer Howard to Timothy Beatley, we can find resurgances of architectural structures that mimic nature, such as green walls; a recent example within Gardens by the Bay in Singapore). These movements all relate to the quest for a stronger individual-environment connection, recapturing personal desires to farm and grow, and seeking the environmental importance of our choices. To minimise this growing divide between self and environment, the 
authors recommend: 1) physical realisation - in the form of incorporating farming principles into daily lifestyles, community gardens, urban and verge farming, and human-scale/individual incorporations of the principles of green urbanism, 2) virtual realisation - in the form of online manifestations, including gaming such as Monopoly and Farmville, rewarding farming-related formulaic success, encouraging cyclical processes and pushing the visual/online landscapes towards appreciating the natural, including connecting/social networking worldwide professionals who may enable change (in a now online public space), and 3) motivating change: framing environmental problems, designing and trialling systems for change (Lehmann \& Crocker, 2013).

Interaction occurs in any space as a result of environment, experience, need and culture. The design of a space relates to individual perceptions and provides people reasons to stop, think and interact. Public space designs can reflect myriad states of mind, our priorities and visions. The levels of interaction increase in well-scaled environments that create ambiance and allow the gathering of similar minds. Carr and colleagues argue that 'the public spaces created by societies serve as a mirror of public and private values as can be seen in the Greek agora, the Roman forum, the New England common, and the contemporary plaza, as well as in Canaletto's scene of Venice' (Carr et al., 1992). Virtually, visual graphics and animations enable connections in the online public domain, firstly with one's self and one's thought processes, then with history, including inter-generational conversations (by reading scanned books, poetry, papers, articles and so on), and thirdly in a public online space (social networking pages-facebook, Google+), through chats, emails and ongoing shared posts (websites and blogs).

In analysing reliance, the history of a place and established/embellished relationships are visible in water's edge public spaces. Colonialism has had deeply ingrained impacts on places, from affecting user identity, self-belief and self-esteem, to the questioning of value and ability. This is apparent when analysing built form, which includes responses to functional requirements, but often goes beyond this to address spiritual, psychological and emotional needs (Moffett et al., 2003). Relationships between individuals and built form can be linked to their past attachment styles, and so too the built form of post-colonial cities (such as Sydney, Hong Kong and Singapore), among other aspects, reflects the effects of colonialism over time.

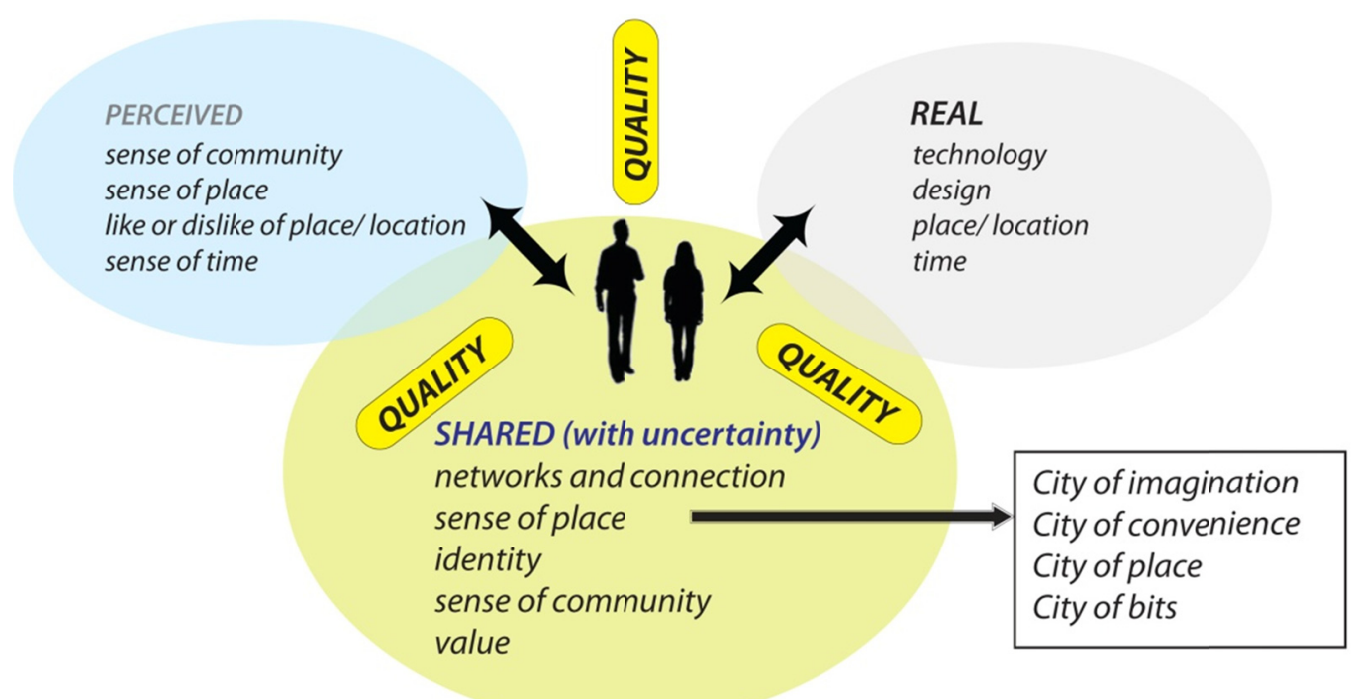

Figure 1. The concept of an individual within a water's edge public space

Figure 1 portrays the three major sub-spheres which contribute to an individual's view of space i.e. real, perceived and shared. In the meantime, the physical water's edge remains open to decoding: relationships and attachments are visibly etched in the chosen spaces. Online, the changing technological landscape is enabled without physical travel or negotiating actual spatial barriers, and yet real, historic and relational cues remain present through people, interaction and their use of words/language, visually and in animation.

Overall, by using the comparative urbanism framework, and analysing individuals and their use of the space, we observe that better re-design of water's edge public spaces can be undertaken. There is a difference in the way designers plan and design waterfront sites due to prominence and impact, the quality of these spaces is seen as 
being crucial to use and functioning. While the process followed is the same, from a concept to built outcome, the designs are up for more scrutiny, and should link more closely with the environment than they currently do.

The differences and similarities between designing 'not on the water's edge' and 'on the water's edge' are presented in Table 1.

Table 1. The differences and similarities between designing any space and designing a water's edge public space

\begin{tabular}{|c|c|c|c|}
\hline DESIGN STAGE & DIFFERENCES & SIMILARITIES & FOCUS \\
\hline \multirow[t]{4}{*}{$\begin{array}{l}\text { CONCEPT AND } \\
\text { INITIAL/PRE-LODGEMENT }\end{array}$} & $\begin{array}{l}\text { Varied options } \\
\text { available because of } \\
\text { presence of land and } \\
\text { water }\end{array}$ & $\begin{array}{l}\text { Basic design processes } \\
\text { remains the same - } \\
\text { creation of a Master } \\
\text { Plan either through a } \\
\text { tender process, } \\
\text { competition etc. }\end{array}$ & $\begin{array}{l}\text { Water, renewable } \\
\text { energies, } \\
\text { environmental and } \\
\text { built form connections, } \\
\text { health and fitness, } \\
\text { options for the better } \\
\text { design of water's edge } \\
\text { public spaces }\end{array}$ \\
\hline & $\begin{array}{l}\text { Ownership may } \\
\text { provide issues in terms } \\
\text { of a large grand design }\end{array}$ & $\begin{array}{l}\text { Designs will focus on } \\
\text { the users and use of } \\
\text { the area (form and } \\
\text { function will be } \\
\text { considered) }\end{array}$ & \\
\hline & $\begin{array}{l}\text { Large amounts of } \\
\text { funding may determine } \\
\text { the project's success or } \\
\text { failure }\end{array}$ & $\begin{array}{l}\text { Funds will be } \\
\text { necessary to progress } \\
\text { the works }\end{array}$ & \\
\hline & $\begin{array}{l}\text { A higher profile } \\
\text { outcome for the city }\end{array}$ & $\begin{array}{l}\text { An updated new } \\
\text { design scheme for the } \\
\text { city }\end{array}$ & \\
\hline $\begin{array}{l}\text { ENVIRONMENTAL } \\
\text { CONSIDERATIONS }\end{array}$ & $\begin{array}{l}\text { Biodiversity, links with } \\
\text { water and } \\
\text { riverine/marine } \\
\text { environment }\end{array}$ & $\begin{array}{l}\text { Project designs to } \\
\text { consider site history, } \\
\text { and a site analysis to } \\
\text { determine } \\
\text { environmental } \\
\text { elements }\end{array}$ & $\begin{array}{l}\text { Maintaining and } \\
\text { enhancing } \\
\text { environmental and } \\
\text { built-form connectivity }\end{array}$ \\
\hline \multirow[t]{3}{*}{$\begin{array}{l}\text { SOCIAL } \\
\text { CONSIDERATIONS }\end{array}$} & $\begin{array}{l}\text { Larger tourist } \\
\text { population traversing } \\
\text { the area }\end{array}$ & $\begin{array}{l}\text { Area used by a range } \\
\text { of people for various } \\
\text { purposes - should be } \\
\text { flexible, changing, } \\
\text { unique and interesting }\end{array}$ & $\begin{array}{l}\text { Connectivity - real and } \\
\text { virtual }\end{array}$ \\
\hline & $\begin{array}{l}\text { Area determines the } \\
\text { view/ perception of the } \\
\text { city }\end{array}$ & $\begin{array}{l}\text { Area to be designed to } \\
\text { be accessible by all } \\
\text { segments of the } \\
\text { population (including } \\
\text { the aged) }\end{array}$ & \\
\hline & $\begin{array}{l}\text { Links with a network } \\
\text { of key places that are }\end{array}$ & & \\
\hline
\end{tabular}


considered important

to the city

\begin{tabular}{llll}
\hline ECONOMIC & A key to improving & Well designed, & Project profile \\
CONSIDERATION AND & tourism and visitor & innovative spaces are & \\
PROJECT MANAGEMENT & numbers in a city & usually well visited
\end{tabular}

A key to the perception

of a city and fostering

of social and cultural

networks within a city

\begin{tabular}{llll} 
CULTURAL & $\begin{array}{l}\text { The historic elements } \\
\text { and stories of the } \\
\text { OoNSIDERATIONS of a city began } \\
\text { at key ports and } \\
\text { waterfronts }\end{array}$ & $\begin{array}{l}\text { Designs to be inclusive } \\
\text { of all cultures }\end{array}$ & $\begin{array}{l}\text { Historic and cultural } \\
\text { links }\end{array}$ \\
& & & \\
\hline
\end{tabular}

\section{Theoretical Context}

\subsection{Comparative Urbanism}

The next logical step in the analysis of water's edge public spaces ensured comparison over time. In her book Ordinary Cities, Jennifer Robinson advances an argument for the removal of entrenched ways of thinking, such as those that state that the East and West have little relevance to each other, with one being modern and the other not. She argues for a more cosmopolitan form of theorising, "one that tracks across different kinds of cities and contexts" (Robinson, 2010). While noting this, there is also a contrary view that "Cities in the developing world cannot have the same strategies and debates as cities in the developed world" (Lehmann, 2012). McFarlane (2010) argues that retaining a broad understanding of comparative thinking informs research and imaginative geographies of the urban, and this is more useful for postcolonial urbanism. The notion of comparison, he says, serves not just as an alternative to caution against integrationist verticalising forms of comparison, but offers an alternative route where theories of the urban might emerge. The outcomes of the pilot study are based in the context of these key ideas. Some Asia-Pacific researchers argue that "the hyper-dense environment of Asia-Pacific cities is a different animal from that of the relatively low density western cities and demands a qualitatively different treatment" (Miao, 2001). Nevertheless, this paper uses comparative urbanism, noting McFarlane's (2010) point that urbanism has always been conceived comparatively. Robinson (2010) argues that, in the past, comparative urbanism has been "shipwrecked on the reef of developmentalism" with "hierarchical categorisation' causing divisions and long-term stuck-on and eroding effects, citing divisive categorisations and terminology such as First/Third, Developed/Developing or North/South. McFarlane also suggests that there is a tendency to compare with the "usual suspects". Also, "by holding one city up as a model, comparative analysis is reduced to a perfunctory and unenlightening assessment of how the "others" compare to the paradigmatic city' (Beauregard, 2003). The authors contend that comparative dissections through time provide a better understanding of specific issues: both overall and within their particular contexts. Therefore, the analysis presented in this paper is an objective comparison of water's edge public spaces in Sydney, Hong Kong and Singapore.

\section{Research Methodology}

This paper uses the comparative urbanism framework to analyse water's edge public spaces. The comparisons were undertaken by visiting and surveying each space. The authors collated this information and identified similarities and differences based on a detailed survey of the case studies. The pilot study results were analysed by comparing case studies in Sydney, Hong Kong and Singapore based on key factors. The comparison was undertaken through the gathering of information using a common questionnaire which was used to analyse all chosen sites. The information gathered related to the categories of: density and use, built form displaying history and re-use, environment and life connections, networks, change and flexibility, and utilising cyclical processes proactively. The links to the types of architectural models were then established. The water's edge public urban spaces chosen as case studies were selected because they display early, mid and emerging lifecycle components, which were selected for this analysis. In this context early is defined as of the $1850-1900$ s or prior, mid is defined as 1950s-2010 and emerging as 2012 onwards. The questionnaire had qualitative and quantitative 
aspects, including videoing and observational analysis of the spaces. The surveys were conducted following each other, in order to best simulate a comparative dissection through time.

\subsection{Case Study Cities}

\subsubsection{Sydney, Hong Kong and Singapore}

In line with the different projected demographic profiles of the East and West, emerging public spaces in the West focus on "access", "connecting" and "networks" (Thompson, 2002), while emerging public spaces in the East focus on "usage by a rising middle class", or mass use, and a growing demand for "comfort" and "security" (Dick \& Rimmer, 1997).

Table 2. The similarities and differences between Sydney, Hong Kong and Singapore (compiled from various sources)

\begin{tabular}{|c|c|c|c|}
\hline & SYDNEY & $H O N G K O N G$ & SINGAPORE \\
\hline Population & 4.6 million & 7.1 million & 5.2 million \\
\hline Area & $12144.6 \mathrm{~km}^{2}$ & $1104 \mathrm{~km}^{2}$ & $710 \mathrm{~km}^{2}$ \\
\hline Average density & $2058 / \mathrm{km}^{2}$ & $6480 / \mathrm{km}^{2}$ & $7315 / \mathrm{km}^{2}$ \\
\hline Planned/fluid & Planned & Planned & Planned \\
\hline Economic breakdown & $\begin{array}{l}\text { Property, business } \\
\text { services, retail, } \\
\text { manufacturing, } \\
\text { health and } \\
\text { community services }\end{array}$ & $\begin{array}{l}\text { Management, finance, IT, } \\
\text { business consultation, } \\
\text { professional services }\end{array}$ & $\begin{array}{l}\text { Hub, corruption free, } \\
\text { market-based } \\
\text { economy, exports, } \\
\text { skilled workforce }\end{array}$ \\
\hline $\begin{array}{l}\text { City make-up/ } \\
\text { residential type }\end{array}$ & $\begin{array}{l}\text { Chain of parklands, } \\
\text { harbour, tourist and } \\
\text { nightlife precinct }\end{array}$ & $\begin{array}{l}\text { Low taxation and free } \\
\text { trade, centre of finance } \\
\text { and trade, over } 7650 \\
\text { skyscrapers, high density, } \\
\text { tall skyline and busy port }\end{array}$ & $\begin{array}{l}\text { Low taxation and free } \\
\text { trade, small island } \\
\text { with high density, } \\
\text { over } 300 \text { parks and } \\
\text { four nature reserves }\end{array}$ \\
\hline Languages spoken & $\begin{array}{l}\text { Global mix: English } \\
(80 \%), \text { Chinese, } \\
\text { Greek, Lebanese, } \\
\text { Turkish and } \\
\text { Vietnamese }\end{array}$ & $\begin{array}{l}\text { Global mix: English and } \\
\text { Chinese, German, } \\
\text { Japanese, Korean, } \\
\text { Vietnamese, other } \\
\text { Southeast Asian and } \\
\text { Middle Eastern }\end{array}$ & $\begin{array}{l}\text { Global mix: Chinese } \\
54.2 \% \text {, English } \\
29.4 \% \text {, Malay } 13.2 \% \text {, } \\
\text { Tamil } 3.1 \%\end{array}$ \\
\hline Infant mortality & $\begin{array}{l}4.61 / 1000 \text { in } \\
\text { Australia }\end{array}$ & $1.3 / 1000$ & $2.32 / 1000$ \\
\hline Suspended particles & (Data not available) & $79 \mathrm{ug} / \mathrm{m}^{3}$ & $35 \mathrm{ug} / \mathrm{m}^{3}$ \\
\hline $\begin{array}{l}\text { Intensity of land use } \\
\text { Central city }\end{array}$ & 20.8 people/ha & 113.8 people/ha & 82.8 people/ha \\
\hline $\begin{array}{l}\text { Intensity of land use } \\
\text { Inner area }\end{array}$ & 32.9 people/ha & 803.9 people/ha & 124.2 people/ha \\
\hline $\begin{array}{l}\text { Intensity of land use } \\
\text { Outer area }\end{array}$ & 15.3 people/ha & 258 people/ha & 80.5 people/ha \\
\hline $\begin{array}{l}\text { Intensity of land use } \\
\text { Metropolitan }\end{array}$ & 16.8 people/ha & 300.5 people/ha & 86.8 people/ha \\
\hline Economic character & $\begin{array}{l}\text { Post-industrial, } \\
\text { finance, immigration }\end{array}$ & $\begin{array}{l}\text { Entrepot, Finance, } \\
\text { Regional HQ }\end{array}$ & $\begin{array}{l}\text { Entrepot, Finance, } \\
\text { Regional HQ }\end{array}$ \\
\hline Functional role & Amenity & Borderless & Borderless \\
\hline
\end{tabular}


As shown in Table 2, the comparisons between Sydney, Hong Kong and Singapore displays geographic consistency, composition, uniqueness, cultural aspects and land density.

In both the East and the West, public spaces have social and psychological, as well as physical, dimensions, within which individuals interact and in which they invest meanings (Bernard et al., 2012; Peace et al., 2007; Peace, Holland, \& Kellaher, 2006). To maintain a connection between the natural sciences, social sciences, planning and architecture, Cuthbert suggests, "we must look much deeper into the human condition" (Cuthbert, 2011). He maintains that such an understanding comes only from a social science-based approach that is currently ignored by the multitudes. Within the human condition are biological processes such as birth, ageing and death, and these very same processes also apply to architectural elements, materials and structures (which connects to architectural science).

The pilot study maintains this analysis of the 'human condition' as the key to examination through a "comparative urbanism lens" (Robinson, 2007). Spaces themselves can be classified based on "internal or external' interaction, and by 'interpersonal' distance. Key ideas in twentieth-century planning re-echo, recycle and connect, and each continues to stem from key individuals (Hall, 2002).

\subsubsection{Sydney}

Sydney is one of the largest cities in the world in terms of area. The metropolitan area of Sydney covers some 1600 square kilometres - equal to London and more than double the size of New York - and the harbour is a defining element of the city. Circular Quay was historically a working part of the city and the now-fashionable The Rocks, was the site of an outbreak of the bubonic plague in 1900 due to its squalid and crowded living conditions. It was only in the 1950s, with the removal of the city's statutory 150 -foot height limit that the waterfront became an attractive commercial location (Marshall, 2001).

\subsubsection{Hong Kong}

Hong Kong bears the imprint of British management and continues to play its historic role as a prime link between the East and the West. It has combined management and economic freedom, resulting in a churning cauldron of activity that's a lot messier than Singapore but no less productive (DAJ, from Glaeser, 2011).

\subsubsection{Singapore}

"Singapore is a legacy of the British East India Company, but it is now a model of superb urban management. It is a hyper-dense city-state with traffic that moves more fluidly than in many small US towns" (Land Transport Authority of Singapore, from Glaeser, 2011).

\subsection{Comparisons of the Cities' Characteristics}

Hong Kong and Singapore have both embarked on a program supporting high-rise living. Urban built up density is high in Singapore, with the majority of residents located on the main island. Despite rapid urbanisation, Singapore has emphasised tree planting, landscaping and open space provisions to maximise environmental capital. Green open spaces and environmental sustainability are considered important elements of high-rise living in Singapore (Yuen \& Yeh, 2011).

Yuen and Yeh (2011) state that Hong Kong and Singapore have the highest densities and largest amount of tall housing in the world. High-density development in Hong Kong is a result of its topography, historical development and land policy. Over 75 per cent of Hong Kong's land consists of hill slopes and a large proportion of the relatively flat areas are under private ownership, making development tricky. Most of the development is concentrated within Kowloon, New Kowloon and Hong Kong Island, where land was obtained through hill levelling and land reclamation by the government.

The Hong Kong government has a policy of dividing land before leasing it to private developers (through auction and tender). The sale of land leases contributes about 30 per cent of the government's total revenue (Yuen \& Yeh, 2011). A geospatial comparison of Sydney, Hong Kong and Singapore is presented in Table 2.

\subsubsection{Cost of Living}

Hong Kong and Singapore rank highly in terms of rental costs compared with Sydney, but Sydney is commonly ranked as having the most expensive cost of living overall followed by Singapore and then Hong Kong. The Australian Government's Economic Intelligence Unit (2011), for example, ranks Sydney as having the highest cost of living followed by Singapore and then Hong Kong. Comparing salaries in the three jurisdictions, for an average top-tier job, a person with five years' work experience will earn A\$140,000 in Sydney and A \$185,000 (for top-tier US firms) and A $\$ 150,000$ (for top-tier UK firms) in Singapore and Hong Kong respectively. The take-home salary is lowest in Sydney, followed by Hong Kong, and largest in Singapore. 
Public transport in Hong Kong and Singapore is generally a third cheaper than in Sydney. For example, a typical long-distance fare costs A $\$ 4.80$ in Sydney, A $\$ 1.60$ in Hong Kong and A $\$ 1.35$ in Singapore. Both Singapore and Hong Kong have extensive rail systems connecting most public places. Sydney's area is larger, its density lower, and the rail network links major public places.

Groceries are generally cheaper in Hong Kong and Singapore than in Sydney. Hong Kong has the cheapest fast food but meals are generally cheapest in Singapore. Utilities are cheapest in Hong Kong, followed by Singapore and then Sydney. Australia charges a goods and services tax (GST) of 10 per cent but Hong Kong does not impose this tax. Singapore charges a seven per cent GST, therefore goods and services taxes are only comparable between Sydney and Singapore.

Clothing is generally cheaper in Singapore and Hong Kong; tailored clothing is cheapest in Hong Kong. Electronic goods are generally cheapest in Singapore, followed by Hong Kong and then Sydney. Selected high-end goods are generally comparable price wise and better sourced in Sydney.

All three cities have vibrant dining and nightlife. Sydney has high-quality restaurants and a developed dining scene. Sporting events and cruises are common in Singapore and Hong Kong, along with dining. Entertainment in all three cities is expensive and the cost differences between the three is not significant.

Various cultural and fiscal factors contribute towards each city's functioning. Overall, Sydney is generally the most expensive of the three cities, except for housing rental, where Hong Kong ranks highest, followed by Singapore, which ranks higher than Sydney.

\section{Architectural Science and Factors Affecting Water's Edge Public Spaces}

Architectural science has historically brought the benefits of science and architecture together, covering fields such as acoustics, lighting, thermal and wind studies, environmental science, psychology and computing (Szokolay, 2008). In this paper, the analysis of sustainable water's edge public spaces is aided by architectural science because architectural science allows the constant referencing of associated fields and conceptual links with evolutionary biology.

\subsection{Architectural Science and Density}

The numbers of people using water's edge public spaces vary based on population, the numbers of visitors and whether the space is used as a transport hub or for recreational and/or cultural and social purposes. Temperature, seasons and weather conditions also affect density. The water's edge spaces in Sydney, Hong Kong and Singapore have different densities and sociocultural uses. The environmental and economic consequences of density have varying effects upon these spaces. Higher densities generally allow greater diversity, as available funding is then usually sufficient to complete larger-scale developments. Designs that mimic biology must not only be aesthetic but must also allow harnessing of biological cycles and processes. Water's edge spaces have areas where biological diversity, ecological and environmental factors and social synergy all intersect through effective design.

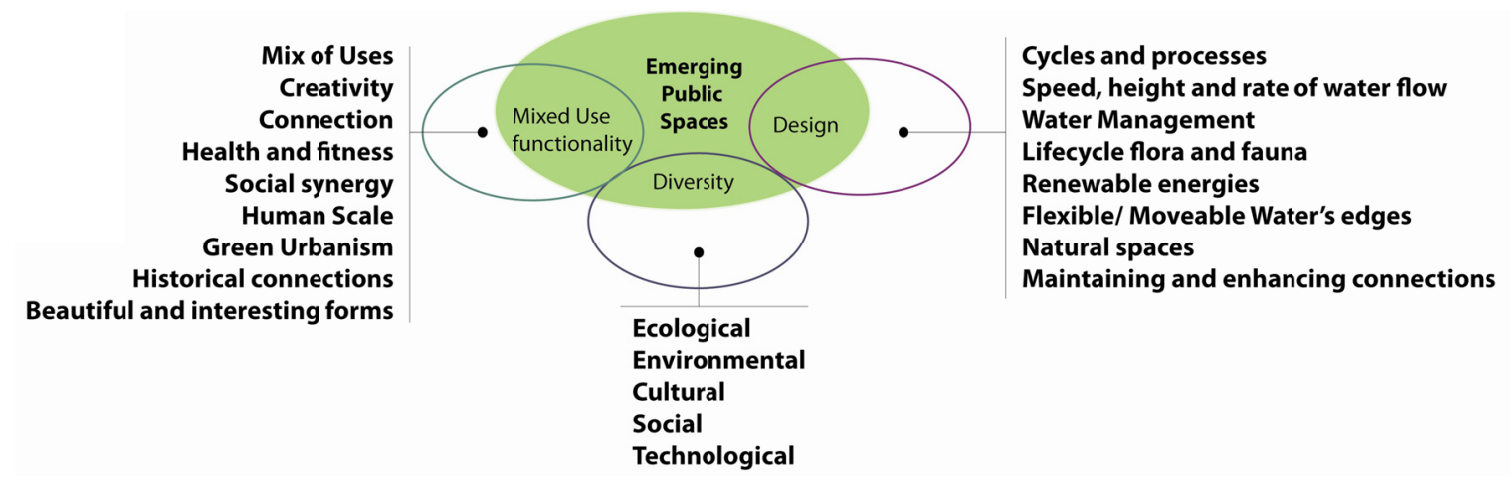

Figure 2. Factors affecting water's edge public spaces: three major aspects - density, diversity and design contribute to biological change of space in time 


\subsection{Architectural Science and Diversity}

Water's edge public spaces were historically situated beside unharnessed riverbanks, seashores, preferred landing docks and green areas that had an ecological reason for existing. These areas directed water flow, naturally prevented overflow, were adaptable to changes in water levels, encouraged environmental diversity and sustained centuries of environmental fluctuations. Today's water's edges may not have similar coping mechanisms, and often need to be redesigned to incorporate environmental strategies.

Environmental pollution is among the challenges when analysing water's edge spaces' biology and diversity. Water's edge spaces are now shifting to primarily recreational uses, and environmental quality is highly regarded. Sydney, Hong Kong and Singapore have come up with various ways to preserve the quality of their emerging green water's edge public spaces (e.g. through design and maintenance). Ecological diversity in green water's edge public areas may be larger, selective and better sustained, and the success of these water's edge public spaces will no doubt be the subject of further research.

\subsection{Architectural Science and Design}

Water's edge public spaces should be designed to contribute systematically to improving the efficiency of ecological and environmental systems over time and enhance their cyclical aspects. Some natural environmental strategies are:

(1) the considered use of architectural design to support biological cycles and processes over time;

(2) the beneficial use of the speed, height and rate of water flow; preventing erosion and sediment movement through biological and structural processes;

(3) creating and maintaining lifecycle flora and fauna (incorporating green urbanism principles);

(4) generating renewable energies based on cyclical and ever-present inputs, i.e. lifecycle of flora, fauna, water flow, sunlight and wind;

(5) creating moveable water's edges that respond favourably to flooding and drought conditions;

(6) allowing natural use, social movement and gatherings in/alongside water's edge spaces; and

(7) maintaining and enhancing recreational, social and online connectivity and networks (to the city, transport, parks and gardens).

\subsection{Architectural Science and Time}

Enhancing the existing system by designing with biology in mind minimises risk by increasing life spans and maintaining existing lifecycles. The use of appropriate construction materials and ensuring processes feed back to overall cyclical processes enables these lifecycles to continue in a self-sustaining manner.
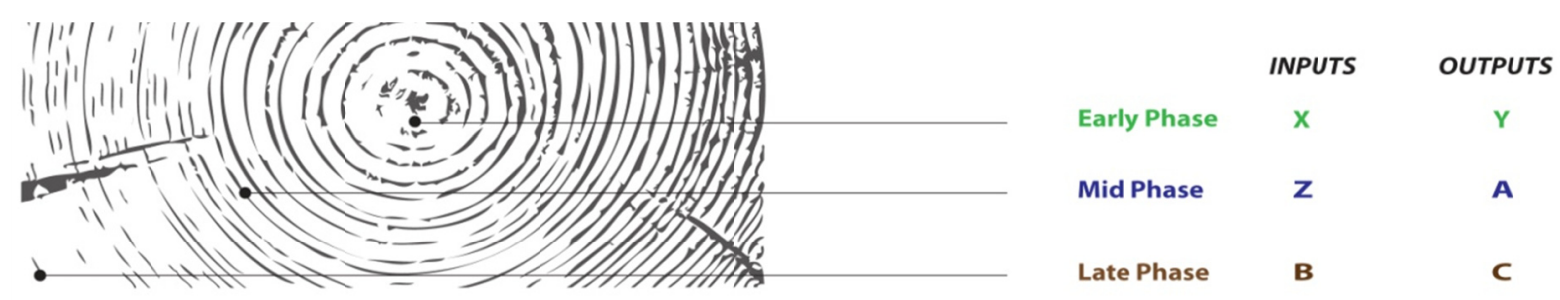

1) Appropriate use of construction materials

2) Designing to incorporate seasonal change, biological cycles and the presence of catalysts

3) Enabling connections between each phase

4) Allowing flexibility of design change over time

5) Maintaining healthy systems - providing the correct inputs at the right times - based on phase, cycles and catalysts

Figure 3. The changing requirements of systems in time - applies to water's edge environments based on phase 


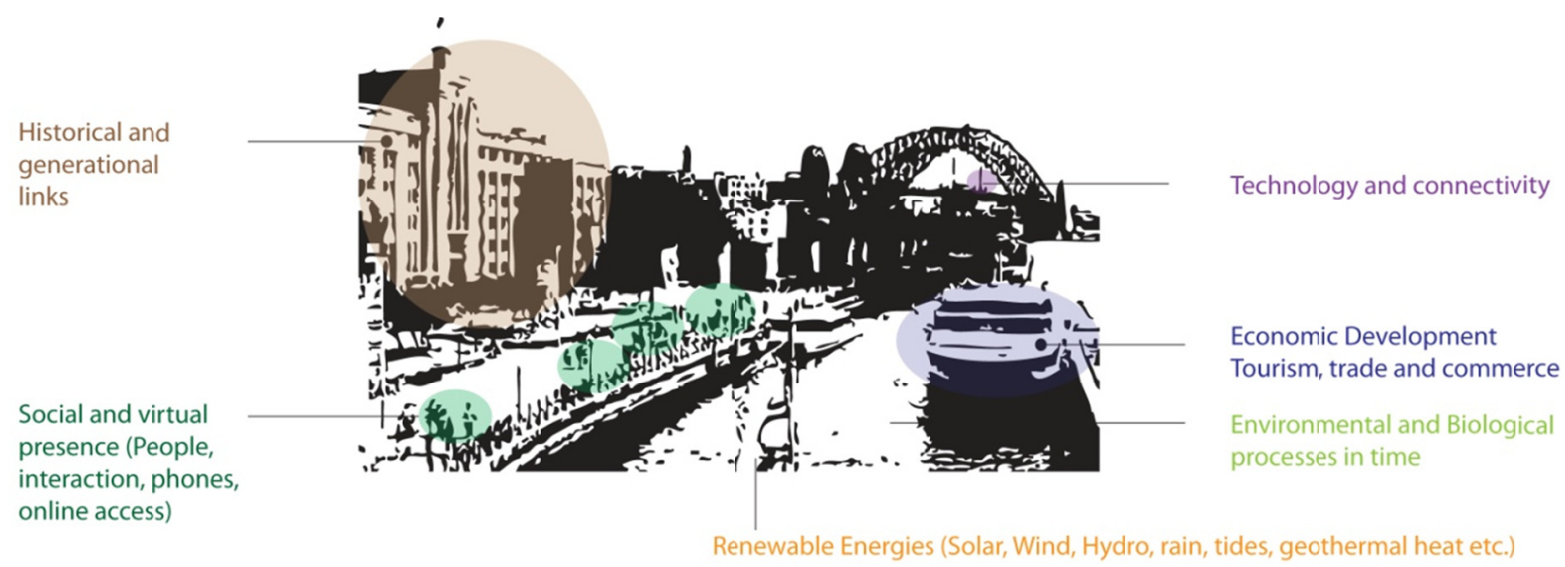

Figure 4. Energies other than traditional non-renewable energies within water's edge public spaces

When considered through a biological and/or farming lens, cognizance of the fourth dimension (time) means consideration of water's edge public spaces in terms of inputs and outputs over time. The needs of the space change with time and the correct inputs are required at the right times to ensure the long-term growth and development of the space.

\section{Conceptual Models of Sustainable Water's Edge Energies and Processes}

\subsection{Energies - from Energy Transfer Spaces to Energy Generation and Storage Spaces}

The flow of energy within existing water's edge public spaces facilitates the success of the space, i.e. the larger the creation, storage, flow and use of energy within a space, the greater the success of the space. Traditional water's edge public spaces are non-renewable energy transferrers and users, whereas emerging ones are renewable energy generators and storers. Energy in this context refers to: 1) physical presence of people - social synergy and social arts/creative, 2) historical/ generational links - built form and identity, 3) economic development - tourism, trade and commerce, 4) technological - enabling the flow of ideas and online connections, 5) environmental and biological, and 6) non-renewable and renewable - solar, hydro, wind and so on.

\subsubsection{Social and Virtual Presence}

Emerging water's edge public spaces display better social and virtual connectivity, compared with that of traditional ones, in the form of organised gatherings and online connections. The density in emerging places is higher and many links exist there.

\subsubsection{Historical and Generational Links - Built Form and Identity}

Well-designed emerging water's edge public spaces maintain historical connection and community participation opportunities, i.e. the adaptive re-use of historical buildings, integrating use of space and improving belonging and participation.

\subsubsection{Economic Development - Tourism, Trade and Commerce}

Historical water's edge public spaces were areas where economic development sparks, tourism, trade and commerce began. These spaces are now in the virtual arena, with more tourism, mixed use and recreational activities now being conducted in emerging water's edge public spaces.

\subsubsection{Technology - Enabling the Flow of Ideas and Online Connections}

Online landscapes, forums and discussion boards through technology (smart phones, tablets and so on) now integrate with water's edge public spaces, enabling the flow of data/ideas and allowing online communication.

\subsubsection{Environmental and Biological Energies}

Emerging public spaces are visibly green, harnessing environmental values of urban heat island mitigation, climate change reduction and green urbanism. Biological energies are being harnessed through ample urban revegetation in water's edge regions to make up for built concrete edges that don't respond well to disaster events. 


\subsubsection{Renewable Energies - Including Solar, Hydro and Wind}

Emerging water's edge public spaces are trying to shift from energy transfer, and use new models for energy generation and storage systems. This involves designs that incorporate solar, hydro, wind and power-harnessing systems.

Water's edge public spaces have avenues where energy transfer and use can be optimised. In studying these avenues, the following biological energy flow, creation and resource-enabling models have been formulated:

A. The branching model (random and repetitive) - transfer of energy - design adapted.

B. The root vegetable model - storage and use of energy - designed for specific use.

C. The equilibrium model - balance of energy dynamics over time - designed to balance energy (natural, created and used - including cycles and seasons).

6Ai. The Branching Model: Random Branching
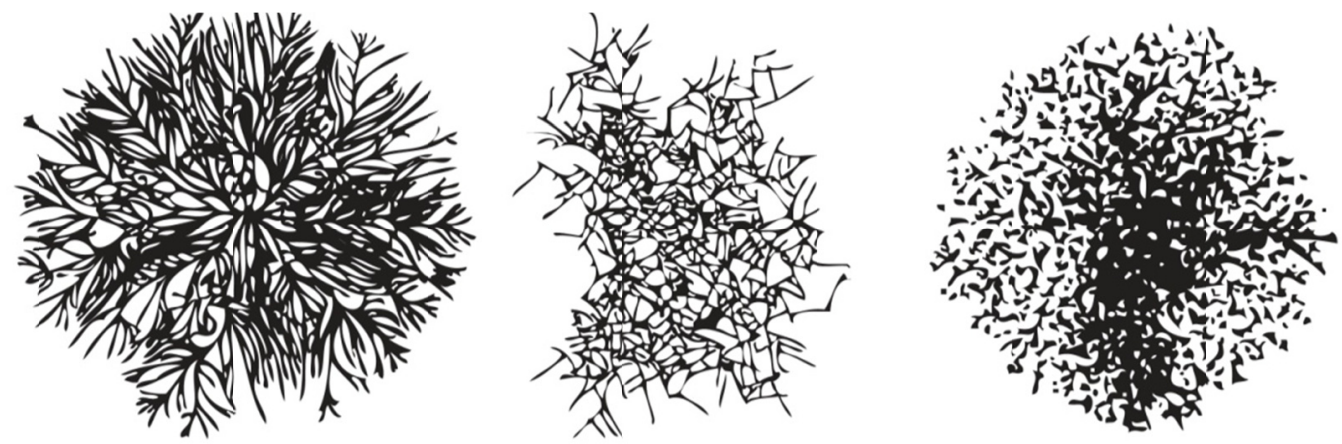

Figure 5. Branches: flow of energy and the creation/enabling of resources

The branching model consists of organised or random energy flows. Through this process various ecologies evolve and are sustained. The choice of materials/form and system configuration enables 'flow on' (resource or energy) and continuity to connected processes.

6Aii. The Branching Model: Repetition and Fractals
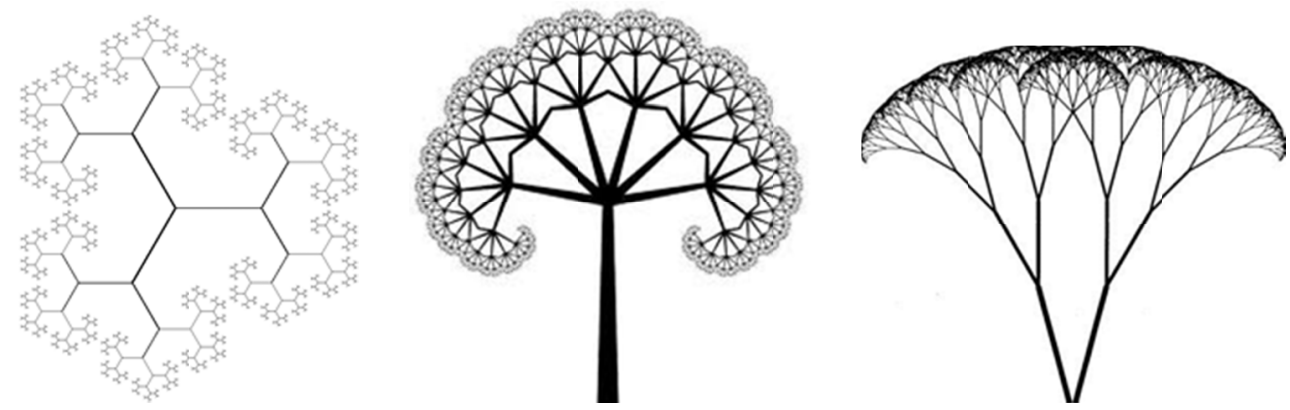

Figure 6. Self-similar branches: flow of energy and the creation/enabling of resources

The patterns of repetition and branching can be formulaic as in the fractal structures above. A stable formula or pattern may repeat itself endlessly so long as energy inputs are constant.

\section{B. The Energy Storage Model}

This model considers that which is not visible but may be crucial to the lifespan of the system, and uncovering the fruit is the outcome of many years of soil fertility and plant dormancy. This model depicts energy that is spent on producing a fruit/outcome, and a biological method of attaining this in design. The tap root stores energy for eventual flower production and the harnessing of biological forms of energy stores. 


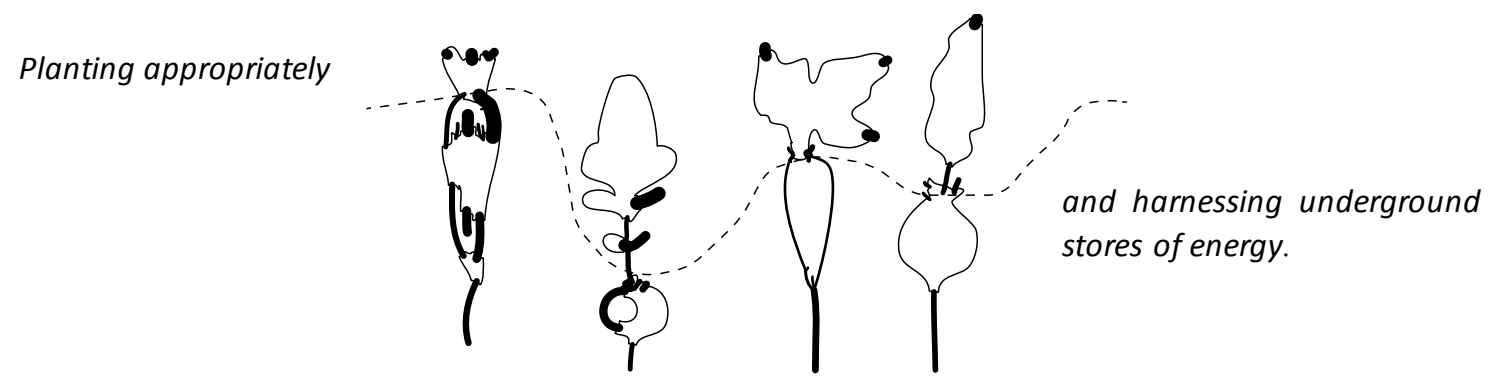

Figure 7. The resultant branching system: flow of energy and the creation/enabling of resources

The models currently available generate energy but the ability to tap into biologically cyclical mechanisms is not exploited. For example, following the farming of a field, another year's harvest is often not dependent on the previous year's crop seeds. Energy is put into water's edge public spaces to generate an outcome, but the cyclical or regenerational aspects/triggers are not considered during design.

6C. The Equilibrium Systemic Model

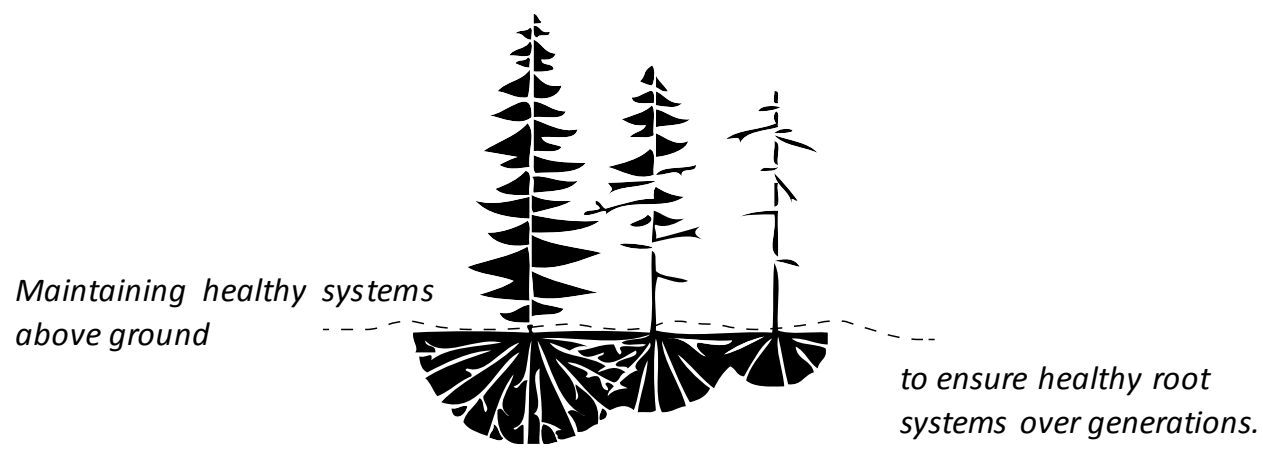

Figure 8 . The balancing dynamics of equilibrium in design (as in nature)

The equilibrium model contains elements of nature, balance, cyclical processes and interdependence. This model depicts cause, effect and required fluctuations as a result of weather, change and seasons. Where branching models are not part of continually nourishing environments, they do not survive over time.

\subsection{Processes in the Design of Sustainable Water's Edge Public Spaces}

The water's edge public spaces presented in this paper acquire balance and a state of dynamic equilibrium, for instance, where they balance sediment transport, discharge and slope (as in Lane's Balance). Lane's Balance is a principle that refers to streams where the velocity of water and discharge of sediments are measured. Designing water beds with smaller-sized sediments would cause the channel to erode and soil to be washed downstream. Lane's Balance makes: 1) the water bed stable, and 2) increases water quality while decreasing sediment loads in the water. Both these factors encourage functionality, health and diversity in ecological systems.

In analysing erraticness in design, floods, tsunamis, droughts and extreme weather conditions provide random occurrences. Current design then deals with these responses through basic and standard building and architectural requirements. Design practices would be strengthened by modelling and mimicking natural systems and biological states.

Analysing proportion and rhythm in design tests more than aesthetic elements. Water's edge public spaces are successful when there are balances between built and natural elements, and flexible rhythms associated with seasonal variations are maintained.

\subsubsection{Stable States, Change in Lifecycles and Overall Progress}

Change occurs due to a shift in variables and a shift in parameters (Figure 9). The variables may change due to catalysts (Figure 10) or the parameters may alter due to seasonal cycles (Figure 11). 


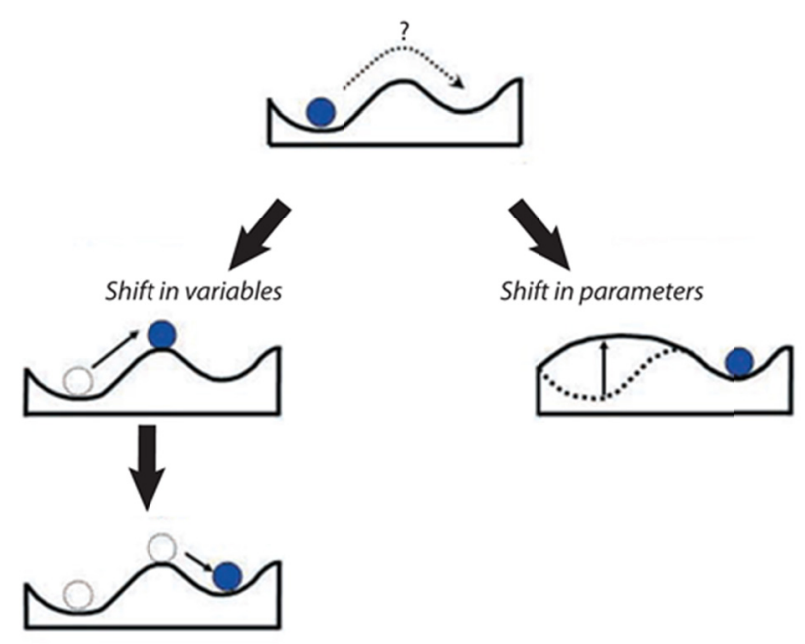

Figure 9. Causes of change and consideration of these causes in Architectural Science. Adapted from "Alternative stable states in ecology" (Beisner et al., 2003) and different types of stability in theoretical communities (Ives \& Carpenter, 2007)

\subsubsection{A The Catalyst: A Shift in Variables}

Catalysts enable the sustainable design of water's edge public spaces in the following ways:

(1) suitable engineering/construction;

(2) allowing and maintaining connections with the site;

(3) minimising long-term adverse effects on the water's edge and water body;

(4) allowing the harnessing of cycles (environmental, ecological, social, technological);

(5) using patterns to benefit the system (climate, temperature, weather fluctuations, flora and fauna, growth and change, soil, predator-prey stable models);

(6) reconsidering use (areas of levels of appropriate human-environment impacts); and

(7) allowing flexibility in movement and change.
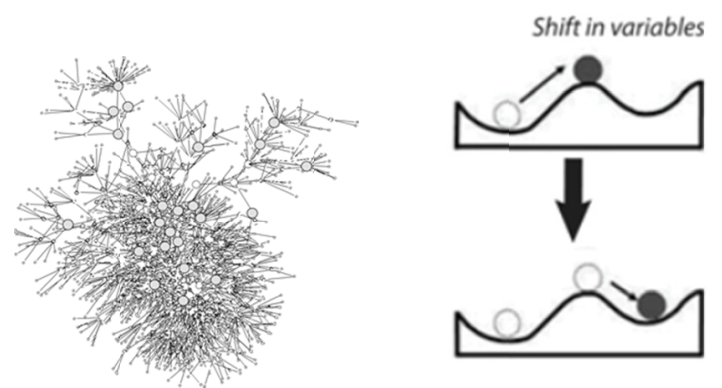

Figure 10. Finding the right catalyst for change: a biological, design, architectural and environmental agenda

\subsubsection{B The Cycles and Seasonal Advantages Model: A Shift in Parameters}

Design that is aware of cyclical and seasonal changes, focuses on the shifts in parameters and allows year-round flexibility, this constitutes sustainable design. This could include consideration of living green walls, flora and fauna, materials, changeability in design of awnings, appropriate use of glass etc. Figure 11 depicts the importance of seasonal variance with reference to the availability of fruits in South Australia and tree foliage.

\section{Pilot Study: Comparative Analysis of Public Spaces}

The pilot study analysed water's edge public spaces in Sydney, Hong Kong and Singapore (see Figures 12-14 and Appendix B) at varying stages of their lifecycles (see Appendix A). Table 3 shows the case studies selected, 
lists the type and nature of the space and identifies which stage of its lifecycle it is at. The pilot study's analysis included an analysis of their design, a consideration of the energy flow in these spaces and application of the conceptual models of energy to them. Table 4 shows which conceptual model of energy is the best fit with the case studies chosen. Based on the stage of the lifecycle that the public space is part of, its need for renewal varies.

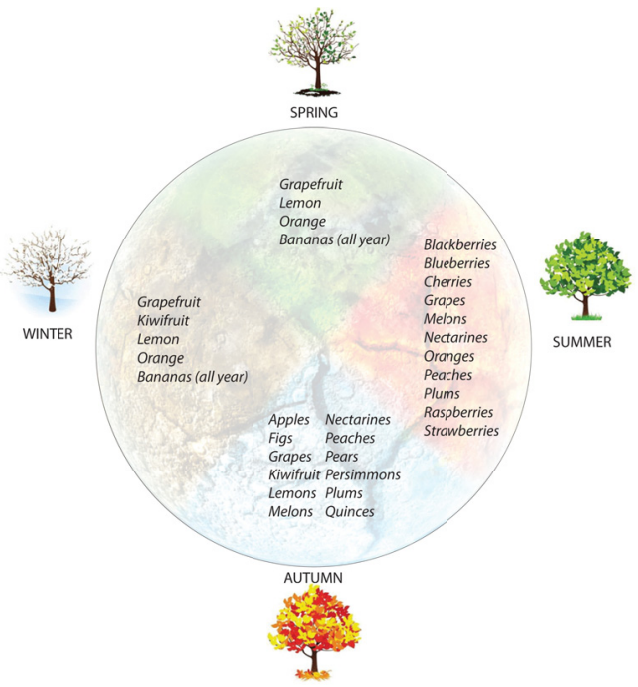

Shift in parameters

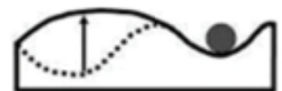

Figure 11. Tapping into cycles to obtain optimal results: seasonal availability of fruit in South Australia

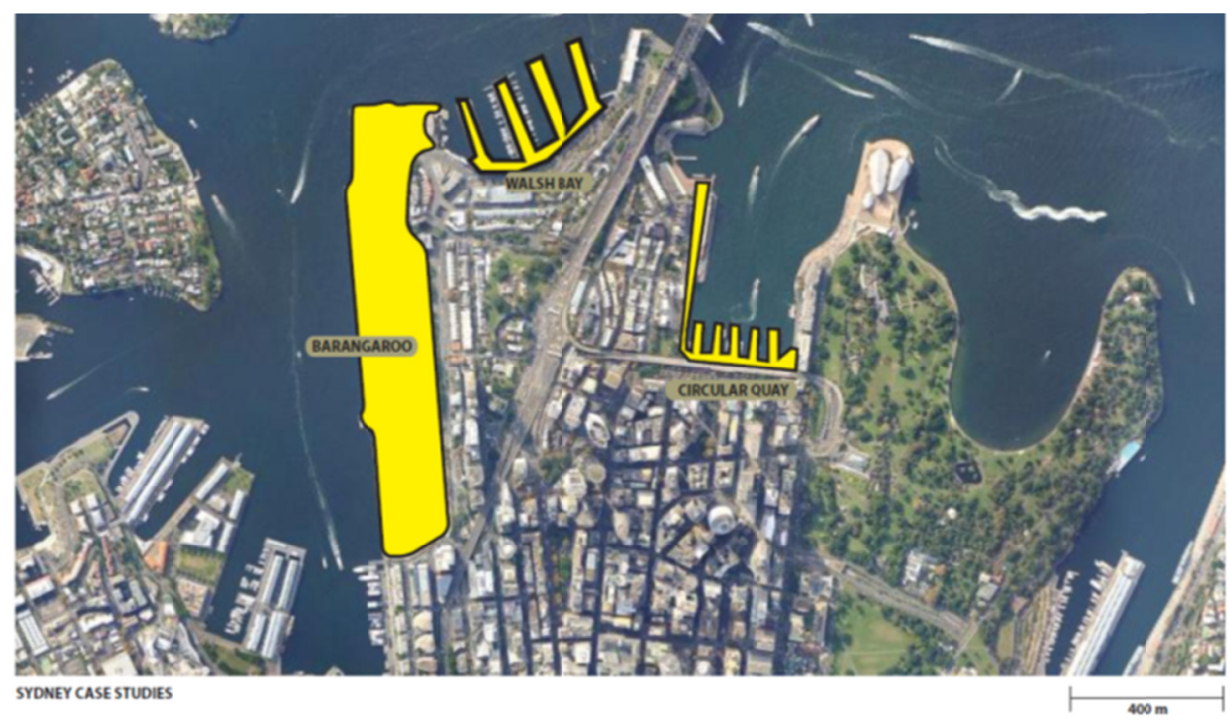

Figure 12. Sydney coastline and waterfront: urban form and case study locations 


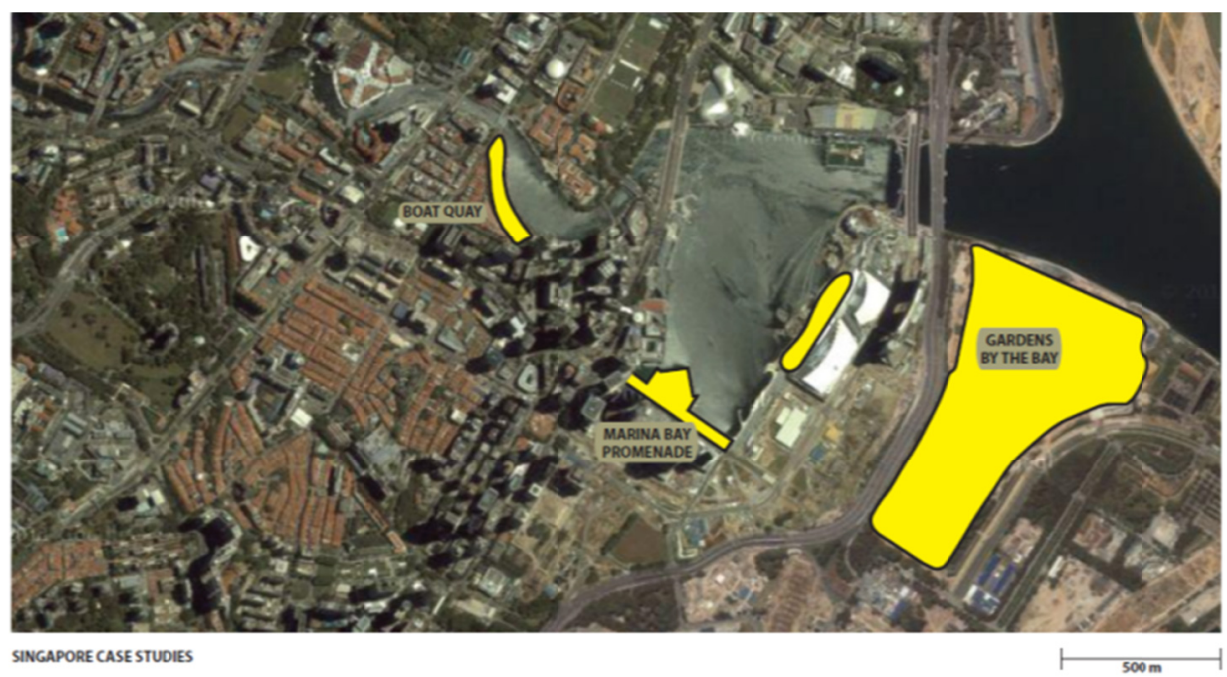

Figure 13. Hong Kong coastline and waterfront: urban form and case study locations

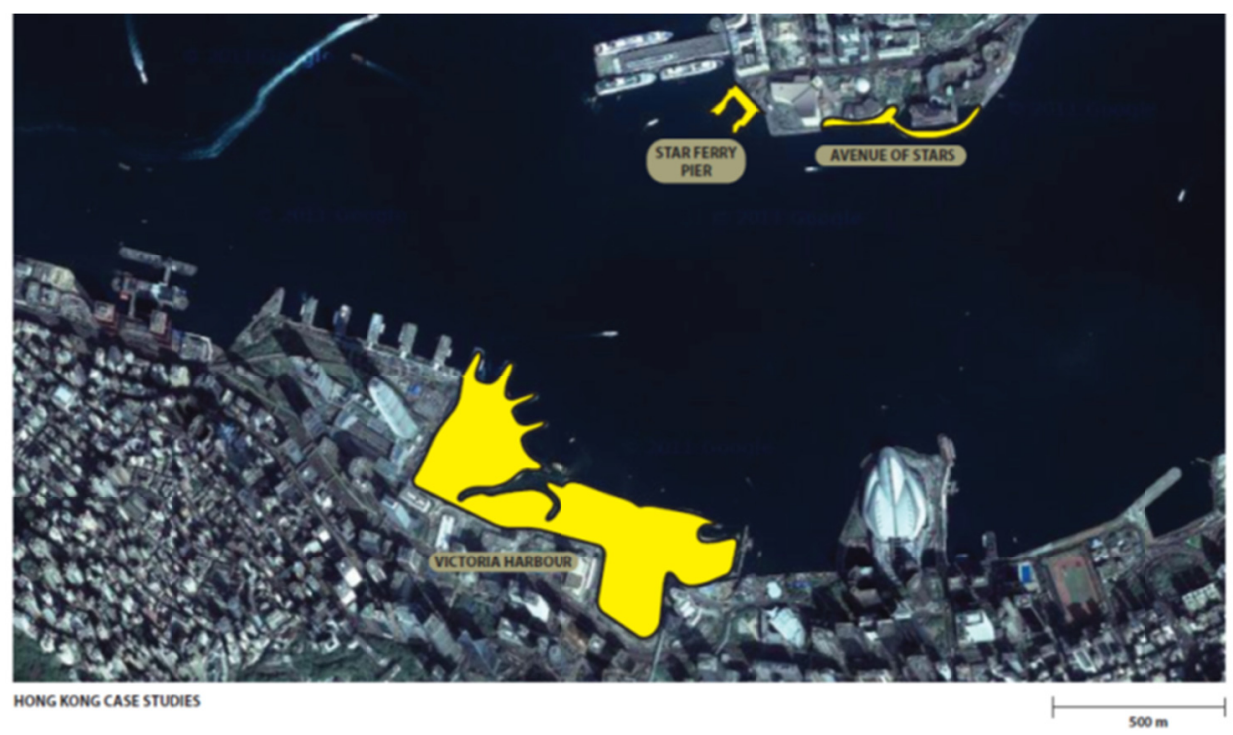

Figure 14. Singapore coastline and waterfront: urban form and case study locations

Table 3. The case studies selected

\begin{tabular}{llll}
\hline & LATE & MID & EMERGING \\
\hline SYDNEY & $\begin{array}{l}\text { Circular Quay } \\
\text { (historical tourist and } \\
\text { transportation hub) }\end{array}$ & $\begin{array}{l}\text { Walsh Bay (residential } \\
\text { mixed use) }\end{array}$ & $\begin{array}{l}\text { Barangaroo (mixed } \\
\text { use) }\end{array}$ \\
\hline \multirow{3}{*}{ HONG KONG } & $\begin{array}{l}\text { Star Ferry Pier } \\
\text { (historical and } \\
\text { transportation hub) }\end{array}$ & $\begin{array}{l}\text { Avenue of Stars } \\
\text { (promenade) }\end{array}$ & $\begin{array}{l}\text { Victoria Harbour } \\
\text { (promenade) }\end{array}$ \\
\hline \multirow{3}{*}{ SINGAPORE } & $\begin{array}{l}\text { vicinity of Raffles and } \\
\text { Fullerton Hotels } \\
\text { (historical and } \\
\text { transportation hub) }\end{array}$ & $\begin{array}{l}\text { Marina Bay } \\
\text { Promenade } \\
\text { (promenade) }\end{array}$ & Gardens by the Bay \\
& & & \\
\hline
\end{tabular}




\section{Results}

The water's edge public spaces in Sydney, Hong Kong and Singapore can be aligned with the following conceptual models (see Table 4).

Table 4. Selected case studies in Sydney, Hong Kong and Singapore and the conceptual model of energy

\begin{tabular}{|c|c|c|c|}
\hline & LATE & $M I D$ & EMERGING \\
\hline \multirow{3}{*}{ SYDNEY } & Circular Quay & Walsh Bay (residential & Barangaroo (mixed use) \\
\hline & BRANCHING & mixed use) ROOT & BRANCHING \\
\hline & & VEGETABLE (storage) & \\
\hline \multirow[b]{2}{*}{ HONG KONG } & Star Ferry Pier & Avenue of Stars & Victoria Harbour \\
\hline & BRANCHING & (promenade) BRANCHING & $\begin{array}{l}\text { ROOT VEGETABLE } \\
\text { (storage) }\end{array}$ \\
\hline \multirow{3}{*}{ SINGAPORE } & vicinity of Raffles and & Marina Bay Promenade & Gardens by the Bay \\
\hline & Fullerton Hotels & (promenade) ROOT & ROOT VEGETABLE \\
\hline & BRANCHING & $\begin{array}{l}\text { VEGETABLE } \\
\text { (storage) }\end{array}$ & (storage) \\
\hline
\end{tabular}

Key aspects of late, mid and emerging public spaces have been determined and listed in Table 5. Public spaces in the mid stages of their lifecycle display harvesting of social potential and solar energy, and emerging public spaces exhibit social synergy, wind and solar energy, biological and environmental inclusion.

Table 5. Selected case studies in Sydney, Hong Kong and Singapore and their inputs and outputs

\begin{tabular}{|c|c|c|c|}
\hline & LATE & $M I D$ & EMERGING \\
\hline \multirow[t]{10}{*}{ SYDNEY } & Circular Quay (historical tourist and & Walsh Bay (residential mixed use) & Barangaroo (mixed use) \\
\hline & transportation hub) & INPUTS: 1) human presence, 2) & INPUTS: 1) design, 2) resources, 3) \\
\hline & INPUTS: 1) human presence, 2) & culture, 3) heritage, 4) avenue of & energy, 4) ecology, 5) buildings, 6) \\
\hline & culture, 3) heritage, 4) time & fitness and health, 5) time & eventual human presence, 7) \\
\hline & OUTPUTS: 1) social synergy, 2) & OUTPUTS: 1) social synergy, 2) arts, & creation of culture, 8 ) heritage \\
\hline & arts, 3) built form adaptation, 4) & 3) built form adaptation, 4) identity, 5) & connections, 9) time \\
\hline & identity, 5) economic development & economic development, 6) cultural & OUTPUTS: 1) social synergy, 2) \\
\hline & & development, 7) social potential & arts, 3) built form adaptation, 4) \\
\hline & & & identity, 5) economic development, \\
\hline & & & 6) tech connections \\
\hline \multirow[t]{4}{*}{ HONG KONG } & Star Ferry Pier (historical and & Avenue of Stars (promenade) & Victoria Harbour (promenade) \\
\hline & transportation hub) & INPUTS: same as above & INPUTS: same as above \\
\hline & INPUTS: same as above & OUTPUTS: same as above & OUTPUTS: same as above + \\
\hline & OUTPUTS: same as above & & energy (wind + solar) \\
\hline \multirow[t]{5}{*}{ SINGAPORE } & vicinity of Raffles and Fullerton & Marina Bay Promenade (promenade) & Gardens by the Bay \\
\hline & Hotels (historical and transportation & INPUTS: same as above & INPUTS: same as above \\
\hline & hub) & OUTPUTS: same as above + energy & OUTPUTS: same as above + \\
\hline & INPUTS: same as above & (solar) & energy (solar + biological + \\
\hline & OUTPUTS: same as above & & environmental) \\
\hline
\end{tabular}


The data gathered and listed above provides the fundamental elements of emerging water's edge public spaces. Amongst other aspects observed, similarities exist between the late, mid and emerging public spaces in Sydney, Hong Kong and Singapore respectively in that the upcoming spaces are harnessing energy and attempting to connect with the environment.

\subsection{Elements of Emerging Water's Edge Public Spaces}

Based on the pilot study, the water's edge public spaces studied display the following characteristics.

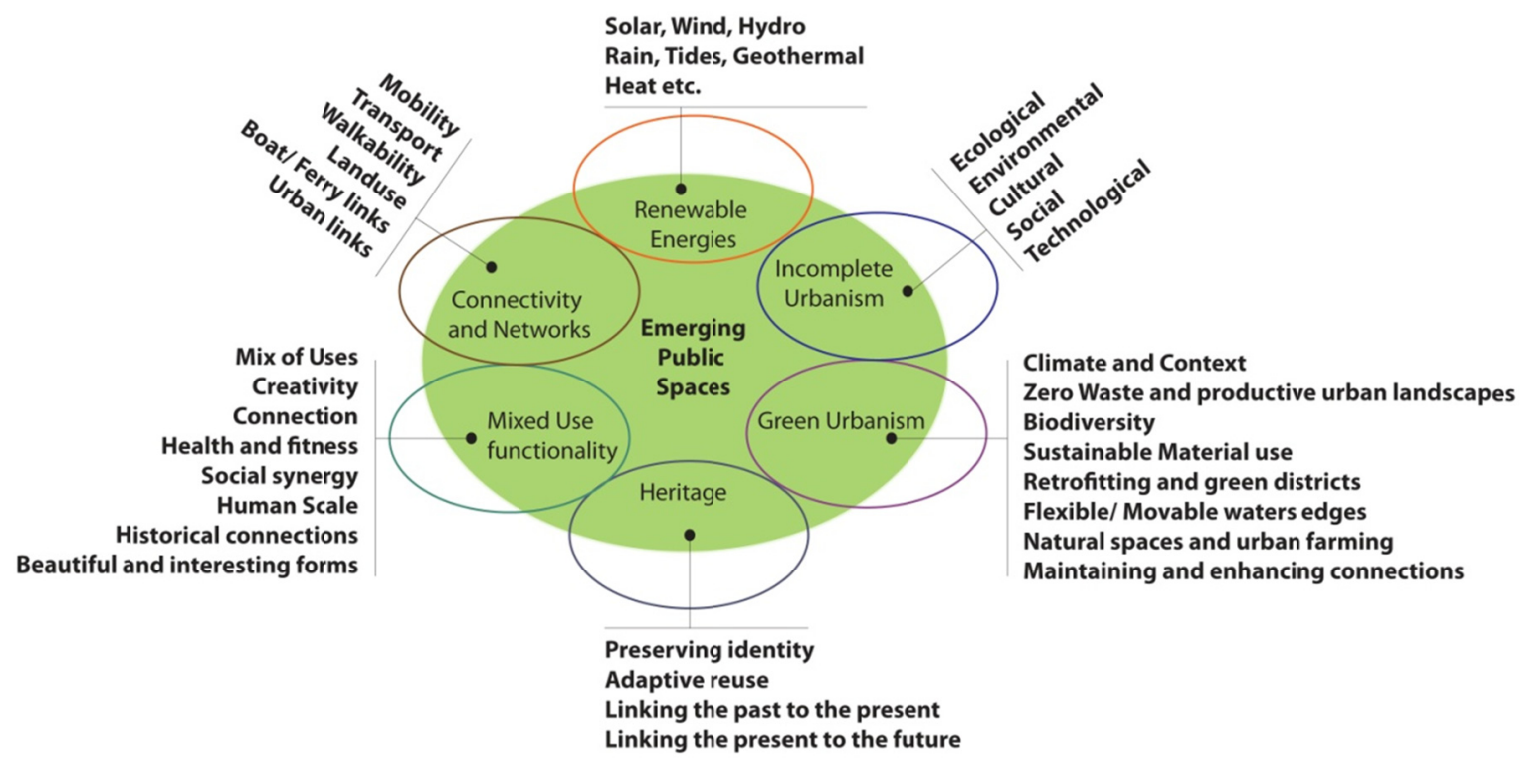

Figure 15. Elements of emerging public spaces

\subsubsection{Mixed Use Functionality}

Mixed and multiple uses of buildings both horizontally (in the form of traditional land use distributions being more condensed and fine grained) and vertically (in the form of various levels or floors having different uses) are apparent in the proximity of the water's edge public spaces studied. In Sydney, the proposed Barangaroo plans display various uses when compared with Circular Quay and Walsh Bay. In Hong Kong, Victoria Harbour displays various uses when compared with Star Ferry Pier and the Avenue of Stars. And in Singapore, Marina Bay, Boat Quay and Gardens by the Bay all have various uses in close proximity to the water's edge, making the place extremely convenient and useful. The 'density and use' corroborates the mixed use functionality in water's edge emerging public spaces.

\subsubsection{Heritage Preservation and Adaptive Re-Use}

Appropriate renovations are often expensive, time consuming and require care in construction. Emerging public spaces display the importance of maintaining connections with the past. History is an essential part of public spaces, and it is often commemorated in plaques, paving and signage. Often these links and/or elements are subtle, and these connections are a major part of specific contemporary public engagement. In Sydney, Walsh Bay displays adaptive re-use in the development of its cultural precinct. In Hong Kong, Star Ferry Pier maintains the historic movements associated with the functional Star Ferry. And in Singapore, Boat Quay maintains the historic ties to the waterfront.

\subsubsection{Green Urbanism}

In assessing social, economic, cultural and architectural connections, we rely on the constancies provided by the environment for seasonal change. Green urbanism makes the necessary connection between urban areas and suburbia. In the water's edge public spaces studied, emerging public spaces are visibly green, and the aspirations for an environmental connection are immediately apparent. Sydney's Barangaroo, Hong Kong's Victoria Harbour and Singapore's Gardens by the Bay all reinforce the importance of green urbanism principles in emerging water's edge public spaces. 
8.1.4 Implementing Technological Connectivity, While Maintaining and Establishing Connections with Urban Networks

In assessing technological connectivity, it is apparent that improvements are required in the public domain to enhance online and spatial connections. Successful water's edge public spaces have historically excelled in functional and interpersonal connectivity. All water's edge public spaces can improve levels of technological connectivity, including their levels of connections to urban networks. Sydney's Circular Quay, Hong Kong's Star Ferry Pier and Singapore's Marina Bay Promenade all display high levels of connectivity with urban networks.

\subsubsection{Allowing Avenues of Incomplete Urbanism}

Cities are constantly evolving, so when assessing avenues of incomplete urbanism, it is important to allow change and flexibility within successful water's edge public spaces. This is displayed in Makansutra in Gluttons Bay, Singapore (where the food stalls are on wheels), the use of Adelaide's riverside venues during the Fringe Festival, and the constant dynamism of change and activity in Hong Kong (i.e. use, connection with Macau and 24-hour activity).

\subsubsection{Harnessing Renewable Energies in the Public Domain}

Singapore's Gardens by the Bay and Marina Bay Promenade have both implemented biological and renewable energy technologies using varying formulas, one grandiose and the other subtle. These water's edge areas aim to utilise renewable energies but may fall short of maintaining a self-sustaining equilibrium that utilises renewable energy, water flow and seasonal and biological cycles. The formula for the success of our water's edge public spaces depends on finding a way in which we can tap into environmental, social, online and cultural methods to enable them to self-sustain over time.

\subsection{Liveability of Cities and Indicators of Sustainability in the Design of Water's Edges}

It is assumed in this paper that improving the quality and design of water's edge public spaces leads directly to benefits in health, wellbeing and transit. Further research needs to be undertaken to establish these relationships in the water's edge public spaces of Sydney, Hong Kong and Singapore. Human behaviour and perception is also a key to unlocking the questions associated with liveability.

Indicators of the sustainable design (within evaluation models) of water's edge public spaces are enabled by:

(1) the branching models, where energy is transferred and used successfully (site use, building/structure orientation, materials, and hydro, wind and solar energy optimisation);

(2) the root vegetable- model, where solar/hydro/wind energy is stored for mass use due to the design and functioning of a building/structure; and,

(3) the equilibrium model, where a building/structure is designed to change with temperature, weather and seasonal conditions - displaying flexibility - and keeps evolving with changing variables (catalysts) and parameters (seasonal and cyclical).

\subsection{Convergence and Divergence Between the East and the West}

\subsubsection{Social}

'Urban waterfronts usually have historical connections, very often including the founding place of a city or its reason for being. These places include opportunities to interpret, portray and personify an area's history, thus urban waterfronts can create a sense of civic pride' (Breen \& Rigby, 1994). The advent of online technologies has altered the previous-locational separations between the East and the West. In analysing Sydney, Hong Kong and Singapore's water's edge public spaces, we note that society's participation in architectural outcomes varies in the East and the West. Over time, the population and its values determine social interaction, but interaction has become easier as it is enabled by technology and connectivity. The cities studied are all global, and the case studies are more comparable now than they were historically.

\subsubsection{Architectural Links}

Historically and visibly, two distinct conceptual forms of public space, namely the Square and the Street, dominate. The Square is essentially a European concept, and the Street, as an interface or bazaar, is an Asian concept. In considering the functioning of the European model, distinct squares historically allowed gathering and interaction, while in the dynamic Asian model, shop-houses traditionally allowed the street to be an interactive public area. As early as 1638, Robert Home suggests, New Haven was laid out in nine regular squares, the central one given over to public use, and this was contemporary with London's first square, at Covent 
Garden. The use of the square in colonial town settlement reflects the influence of London, and indeed the square has been called 'London's principal contribution to town planning' (Home, 1997).

In Sydney, Hong Kong and Singapore, buildings by the world's signature architects are prominent, providing a measure of their influence through their work, leaving a cosmopolitan culture, allowing the shift from territorial-based to global architecture. In light of recent global economic turmoil i.e. the economic recession starting in 2008, it is unclear if this will continue.

In the Rocks area, Sydney displays a retention of history that is unparalleled, for example, the 'Nurses Walk', along Sydney Harbour, while Hong Kong's Star Ferry Pier provides an operational and active historical reference. Similarly, Singapore provides a quaint reminder of heritage in its much-valued Fullerton Hotel.

The Sydney, Hong Kong and Singapore cases studied display convergence while retaining social and cultural differences.

\subsubsection{Cultural}

Historically, plans were based on 'segregation of races' with public spaces such as parks used as buffers in all cities studied. For example, in Singapore, a European Residential Area was segregated by a park, but this became unacceptable in the Second World War, and was later renamed a Government Residential Area (Evans \& Pirie, 1939). In the 1980s and 1990s, rapid transformations took place, waterfronts became frontiers where new forces for change were thrown into sharp relief (Dovey, 2005) and many waterfront revitalisation projects took place.

The Sydney, Hong Kong and Singapore cases studied display variation in social and cultural aspects but similarities in terms of: 1) mixed use functionality, 2) heritage preservation and adaptive re-use, 3) green urbanism, 4) connectivity, 5) incomplete urbanism and 6) renewable energies.

\subsection{The Sustainable Design of Water's Edge Public Spaces}

The effective design of water's edge public spaces includes consideration of, firstly, individual interaction with the environment; secondly, socioeconomic and environmental factors in design; thirdly, maintaining biological connectivity through design (green urbanism, harnessing solar, wind and environmental synergies); and fourthly, considering the variables (catalysts) and changing parameters (cycles, seasons) - all this in the context of set indicators for sustainable design that are enabled by specified models. The sustainable design of water's edge public spaces will be enabled through a clearer incorporation of Architectural Science in design, especially through the incorporation of biological, agricultural and ecological concepts in design.

\subsection{The Renewal of Existing Water's Edge Public Spaces}

Existing water's edge public spaces are more difficult to upgrade due to existing challenges such as heritage preservation requirements, use, functioning and tradition. Renewal of these sites may be undertaken through consideration of scale, pedestrian flow, recreational and functional use, and value-adding pursuits, incorporating aspects of emerging public spaces and sustainable design in a strategic manner.

The challenge is not in understanding that guidelines for each area will be different based on context, but in adopting a method that is viable over many generations.

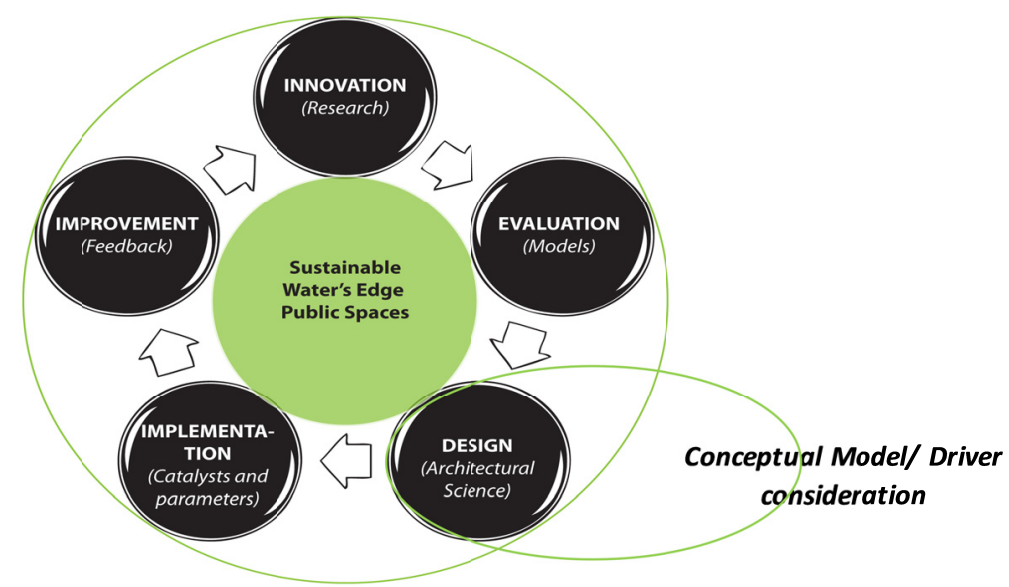

Figure 16. Key steps to achieving sustainable renewal of water's edge public spaces 


\section{Conclusion}

This paper analysed emerging water's edge public spaces in three Asia-Pacific cities and determined that these public spaces: 1) encourage mixed use functionality, 2) preserve heritage and encourage adaptive re-use, 3) promote green urbanism, 4) implement technological connectivity while maintaining and establishing connections to urban networks, 5) allow avenues of incomplete urbanism, and 6) harness renewable energies in the public domain. Water's edge developments are a key to the identity and perceived image of the selected cities, causing significant social and economic benefits to health and wellbeing, welfare, belonging, trade/commerce and innovation.

Functionally, the case study cities have different drivers and approaches, and their histories and contexts remain unique. Differences exist in terms of society and culture, and similarities exist in these emerging water's edge public spaces in terms of environmental connections, energy harnessing and want of social diversity.

The authors found that a further outcome of this study was that though commonalities exist, specific differences exist, based on context in the handling of water's edge public spaces in the chosen cities, hence the use of comparative urbanism, the study of individuals in public spaces and the focus on connection, interaction and reliance. While Sydney displays user participation and a patchwork approach to development and upgrade, Hong Kong is going through a new awakening to heritage, exhibiting retrofitting and large redevelopment projects, and Singapore demonstrates the benefits of a grand new vision through reinvention and large-scale development of the waterfront. Lessons can be learnt from the different approaches, each of which provides sustainable outcomes to varying degrees.

This paper suggests that a greater incorporation of architectural science is needed in initial stages of design to maintain required links between biological/seasonal cycles, environmental connections and processes in time. The implications for sustainability, liveability and urban renewal as a result of the incorporation of architectural science in the initial stages of design will be enormous. The relationships between Eastern and Western cities are continually changing and maturing and the water's edge public spaces studied emphasise this connection, while encouraging the development of valued social, architectural and cultural links over time.

\section{Acknowledgements}

This study received financial support from the Zero Waste Research Centre for Sustainable Design and Behaviour ( $\mathrm{sd}+\mathrm{b}$ Centre) at the University of South Australia. The authors are grateful to colleagues (especially Katharine Thornton for editing), and others who provided comments on earlier drafts, and to reviewers for constructive suggestions that helped improve this paper.

\section{References}

Australian Government. (2012). Australia in the Asian Century. White Paper, Australia in the Asian Century Implementation Task Force, Canberra, ACT.

Banerjee, T. (2001). The future of public space: Beyond invented streets and reinvented places. APA Journal, 67(1), 9-24.

Beatley, T. (2011). Biophilic Cities: Integrating Nature into Urban Design and Planning. Island Press, London. http://dx.doi.org/10.5822/978-1-59726-986-5

Beatley, T., \& Newman, P. (2008). Green Urbanism Down Under: Learning from Australia's Sustainable Communities. Island Press, Washington, DC.

Beauregard, R. A. (2003). City of superlatives. City and Community, 2(3), 183-199. http://dx.doi.org/10.1111/1540-6040.00049

Beisner, B. E., Haydon, D. T., \& Cuddington, K. (2003). Alternative stable states in ecology. Frontiers in $\begin{array}{lllll}\text { Ecology and the } & \text { Environment, }\end{array}$ http://dx.doi.org/10.1890/1540-9295(2003)001[0376:ASSIE]2.0.CO;2

Bernard, M., Liddle, J., Bartlam, B., Scharf, T., \& Sim, J. (2012). Then and now: Evolving community in the context of a retirement village. Ageing and Society, 32(1), 103. http://dx.doi.org/10.1017/S0144686X11000079

Breen, A., \& Rigby, D. (1994). Waterfronts: Cities Reclaim their Edge. McGraw-Hill Inc., USA.

Carr, S., Francis, M., Rivlin, L. G., \& Stone, A. M. (1992). Public Space. Cambridge University Press, Cambridge.

Cuthbert, A. R. (2011). Understanding Cities: Method in urban design. Routledge, New York. 
Deelstra, T., \& Girardet, H. (2000). Urban agriculture and sustainable cities. In N. Bakker, M. Dubbeling, S. Gundel, U. Sabel-Koschela, H. de Zeeuw (eds), Growing Cities, Growing Food: Urban Agriculture on the Policy Agenda (pp. 43-65). Deutsche Stiftung für Internationale Entwicklung: Feldafing, Germany.

Dick, H. W., \& Rimmer, P. J. (1997). Beyond the Third World City: The New Urban Geography of South-east Asia. Urban Studies, 35(12), 2303-2321. http://dx.doi.org/10.1080/0042098983890

Dovey, K. (2005). Fluid City: Transforming Melbourne's Urban Waterfront. Routledge, Sydney, Australia.

Economic Intelligence Unit. (2011). A summary of Liveability and Ranking. Federal Government of Australia, Canberra.

Evans, F. D., \& Pirie, G. J. (1939). Selection of Sites for Towns and Government Residential Areas. Lagos, Government Printer.

Gehl, J., \& Matan, A. (2009). Two perspectives on public spaces. Building Research and Information, 37, 106. http://dx.doi.org/10.1080/09613210802519293

Giles-Corti, B. (2006). The impact of urban form on public health. Australian State of the Environment Committee, Department of the Environment and Heritage, Canberra.

Glaeser, E. (2011). Triumph of the City: How Our Greatest Invention Makes Us Richer, Smarter, Greener, Healthier, and Happier. Penguin Books, New York.

Hall, P. (2002). Cities of tomorrow: An intellectual history of urban planning and design in the twentieth century. Blackwell, Oxford.

Home, R. (1997). Of Planting and Planning: The making of British colonial cities. London, UK: Spon Press.

Ives, A. R., \& Carpenter, S. R. (2007). Stability and diversity of ecosystems. Science, 317, 58-62. http://dx.doi.org/10.1126/science.1133258

Karuppannan, S., \& Sivam, A. (2011). Social sustainability and neighbourhood design: An investigation of $\begin{array}{llllll}\text { residents satisfaction in Delhi. Local Environment, } & 16(9), & 849 .\end{array}$ http://dx.doi.org/10.1080/13549839.2011.607159

Lehmann, S. (2012). Green urbanism: Formulating a series of holistic principles. In T. Haas (ed.), Sustainable Urbanism and Beyond: Rethinking Cities for the Future. Rizzoli, New York.

Lehmann, S., \& Crocker, R. (2013). Motivating change: Sustainable design and behaviour in the built environment. Earthscan, Routledge, London.

Lim, W. (2012). Incomplete Urbanism: A Critical Urban Strategy for Emerging Economies. World Scientific Publishing, Singapore.

Marshall, R. (2001). Waterfronts in Post-Industrial Cities. Spon Press, London.

McFarlane, C. (2010). The city as assemblage: dwelling and urban space. Environment and Planning D: Society and Space, 29(4), 649-671. http://dx.doi.org/10.1068/d4710

Miao, P. (2001). Public places in Asia Pacific cities: Current issues and strategies. Netherlands: Kluwer Academic Publishers. http://dx.doi.org/10.1007/978-94-017-2815-7

Mitchell, W. (1995). City of Bits: Space, Place and the Infobahn. Cambridge, Massachussetts: MIT Press.

Moffett, M., Fazio, M., \& Wodehouse, L. (2001). A World History of Architecture. Laurence King, London.

Peace, S., Holland, C., \& Kellaher, L. (2005). The influence of neighbourhood and community on well-being and identity in later life: An English perspective. In G. D. Rowles, \& H. Chaudhury (eds), Home and Identity in Late Life: International Perspectives. Springer, New York.

Peattie, L. (1998). Convivial cities. In J. Friedman, \& M. Douglass (eds), Cities for citizens: Planning and the rise of civil society in a global age. New York: John Wiley \& Sons.

Powell, R. (2000). Singapore: Architecture of a Global City. Archipelago Press, Singapore.

Pugalis, L. (2009). The culture and economics of urban public space design: Public and professional perceptions. Urban Design International, 14(4), 215-230. Palgrave Macmillan. http://dx.doi.org/10.1057/udi.2009.23

Robinson, J. (2006). Ordinary Cities: Between Modernity and Development. Routledge, London.

Robinson, J. (2007). Developing ordinary cities: City visioning processes in Durban and Johannesburg. Environment and Planning, 40, 74-87. http://dx.doi.org/10.1068/a39127 
Shaftoe, H. (2008). Convivial Public Spaces: Creating Effective Public Places. Earthscan, Routledge, London.

Sivam, A., Karuppannan, S., \& Koohsari, J. M. (2012). Does Urban Design Influence Physical Activity in the Reduction of Obesity? A Review of Evidence. The Open Urban Studies Journal, 5, 14-21. http://dx.doi.org/10.2174/1874942901205010014

Smith, H., \& Soledad, M. (eds). (2012). Waterfront Regeneration: Experiences in City-Building. Earthscan, Routledge, Oxon.

Szokolay, S. (2008). Introduction to Architctural Science: the basis of Sustainable Design. Routledge, Architectural Press, UK.

Thompson, C. W. (2002). Urban open space in the $21^{\text {st }}$ century. Landscape and Urban Planning, 60(2), 59-72. http://dx.doi.org/10.1016/S0169-2046(02)00059-2

Worthington, J. (2009). Urban Form for a Sustainable Future: How Sustainable Is Distributed Working in the Networked City? Journal of Green Building, 4(4), 148-157. http://dx.doi.org/10.3992/jgb.4.4.148

Wu, R., \& Canham, S. (2008). Portraits from Above: Hong Kong's Informal Rooftop Communities. Peperoni Books, Hong Kong.

Yin, R. K. (2003). Case Study Research: Design and Methods (3rd ed.). Sage, Thousand Oaks, CA.

Yuen, B., \& Yeh, G. O. (2011). High-rise Living in Asian Cities. Springer, Dordrecht. http://dx.doi.org/10.1007/978-90-481-9738-5 


\section{Appendix A}

Water's edge public spaces in Sydney, Hong Kong and Singapore: information gathered

Table 6. Density and Use

\begin{tabular}{llll}
\hline & HIGH & MEDIUM & LOW \\
\hline SYDNEY & Circular Quay & Walsh Bay & Barangaroo \\
\hline HONG KONG & Victoria Harbour & Star Ferry Pier & Avenue of Stars \\
\hline SINGAPORE & Marina Bay & Boat Quay & Gardens by the Bay \\
\hline
\end{tabular}

Table 7. Built form encouraging history and re-use

\begin{tabular}{|c|c|c|c|}
\hline & $H I G H$ & MEDIUM & LOW \\
\hline \multicolumn{4}{|l|}{ SYDNEY } \\
\hline Circular Quay & $\mathrm{X}$ & & \\
\hline Walsh Bay & & $\mathrm{X}$ & \\
\hline Barangaroo & & & $\mathrm{X}$ \\
\hline \multicolumn{4}{|l|}{ HONG KONG } \\
\hline Victoria Harbour & & & $\mathrm{X}$ \\
\hline Star Ferry Pier & $\mathrm{X}$ & & \\
\hline Avenue of Stars & & & $\mathrm{X}$ \\
\hline \multicolumn{4}{|l|}{ SINGAPORE } \\
\hline Marina Bay & $\mathrm{X}$ & & \\
\hline Boat Quay & $\mathrm{X}$ & & \\
\hline Gardens by the Bay & & & $\mathrm{X}$ \\
\hline
\end{tabular}

Table 8. Environment and life connections

\begin{tabular}{lccc}
\hline & HIGH & MEDIUM & LOW \\
\hline SYDNEY & & $\mathrm{X}$ & $\mathrm{X}$ \\
$\begin{array}{l}\text { Circular Quay } \\
\text { Walsh Bay } \\
\text { Barangaroo }\end{array}$ & $\mathrm{X}$ & \\
\hline HONG KONG & $\mathrm{X}$ & \\
Victoria Harbour & $\mathrm{X}$ & $\mathrm{X}$ & \\
Star Ferry Pier & & $\mathrm{X}$ & \\
Avenue of Stars & & $\mathrm{X}$ & \\
\hline SINGAPORE & & & \\
Marina Bay & & $\mathrm{X}$ & \\
Boat Quay & & \\
Gardens by the Bay & &
\end{tabular}


Table 9. Networking with adjoining spaces

\begin{tabular}{lccc}
\hline & HIGH & MEDIUM & LOW \\
\hline $\begin{array}{l}\text { SYDNEY } \\
\text { Circular Quay }\end{array}$ & $\mathrm{X}$ & $\mathrm{X}$ & \\
$\begin{array}{l}\text { Walsh Bay } \\
\text { Barangaroo }\end{array}$ & & & \\
\hline HONG KONG & $\mathrm{X}$ & $\mathrm{X}$ \\
Victoria Harbour & $\mathrm{X}$ & & \\
Star Ferry Pier & & & \\
Avenue of Stars & $\mathrm{X}$ & & \\
\hline SINGAPORE & $\mathrm{X}$ & \\
Marina Bay & $\mathrm{X}$ & \\
Boat Quay & & \\
Gardens by the Bay & & \\
\hline
\end{tabular}

Table 10. Change and flexibility

\begin{tabular}{|c|c|c|c|}
\hline & $H I G H$ & MEDIUM & $L O W$ \\
\hline \multicolumn{4}{|l|}{ SYDNEY } \\
\hline Circular Quay & & & $\mathrm{X}$ \\
\hline Walsh Bay & & $\mathrm{X}$ & \\
\hline Barangaroo & $\mathrm{X}$ & & \\
\hline \multicolumn{4}{|l|}{ HONG KONG } \\
\hline Victoria Harbour & $\mathrm{X}$ & & \\
\hline Star Ferry Pier & & & $\mathrm{X}$ \\
\hline Avenue of Stars & & $\mathrm{X}$ & \\
\hline \multicolumn{4}{|l|}{ SINGAPORE } \\
\hline Marina Bay & $\mathrm{X}$ & & \\
\hline Boat Quay & & & $\mathrm{X}$ \\
\hline Gardens by the Bay & $\mathrm{X}$ & & \\
\hline
\end{tabular}

Table 11. Proactive utilisation of cyclical processes

\begin{tabular}{lccc}
\hline & HIGH & MEDIUM & LOW \\
\hline $\begin{array}{l}\text { SYDNEY } \\
\text { Circular Quay }\end{array}$ & & & $\mathrm{X}$ \\
$\begin{array}{l}\text { Walsh Bay } \\
\text { Barangaroo }\end{array}$ & $\mathrm{X}$ & & \\
\hline HONG KONG & $\mathrm{X}$ & & \\
$\begin{array}{l}\text { Victoria Harbour } \\
\text { Star Ferry Pier }\end{array}$ & $\mathrm{X}$ & & \\
Avenue of Stars & & & \\
\hline $\begin{array}{l}\text { SINGAPORE } \\
\text { Marina Bay }\end{array}$ & $\mathrm{X}$ & $\mathrm{X}$ \\
Boat Quay & $\mathrm{X}$ & \\
Gardens by the Bay & & & \\
\hline
\end{tabular}




\section{Appendix B}

\section{Case study sites: Sydney, Hong Kong and Singapore}
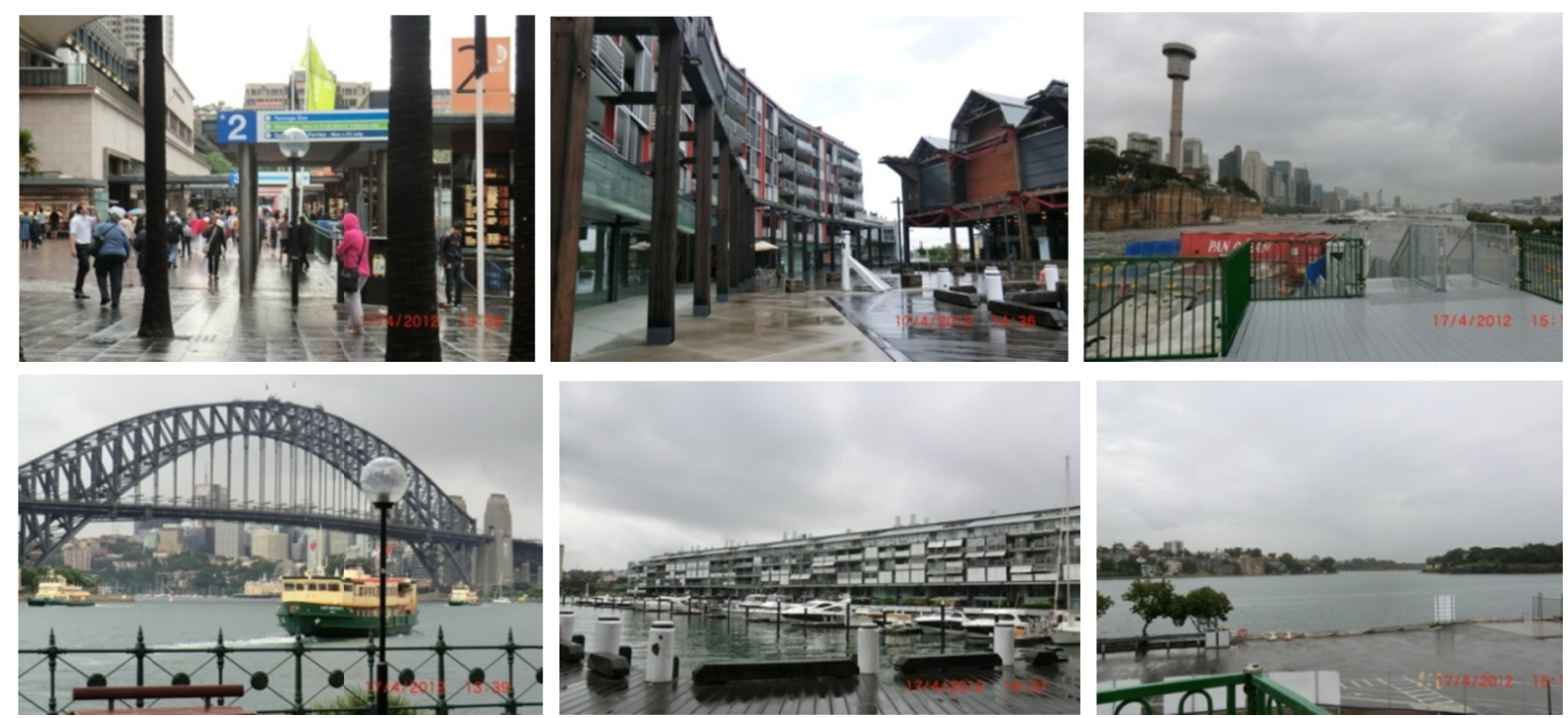

Figure 17. Sydney (left to right): Circular Quay, Walsh Bay and Barangaroo
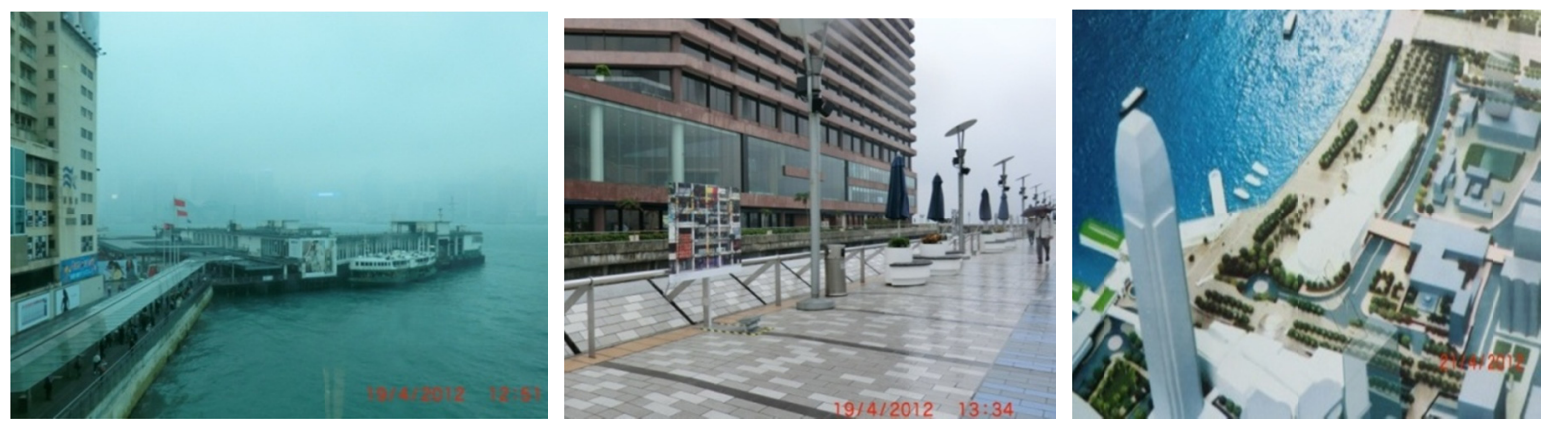

Figure 18. Hong Kong (left to right): Star Ferry Pier, Avenue of Stars and Victoria Harbour
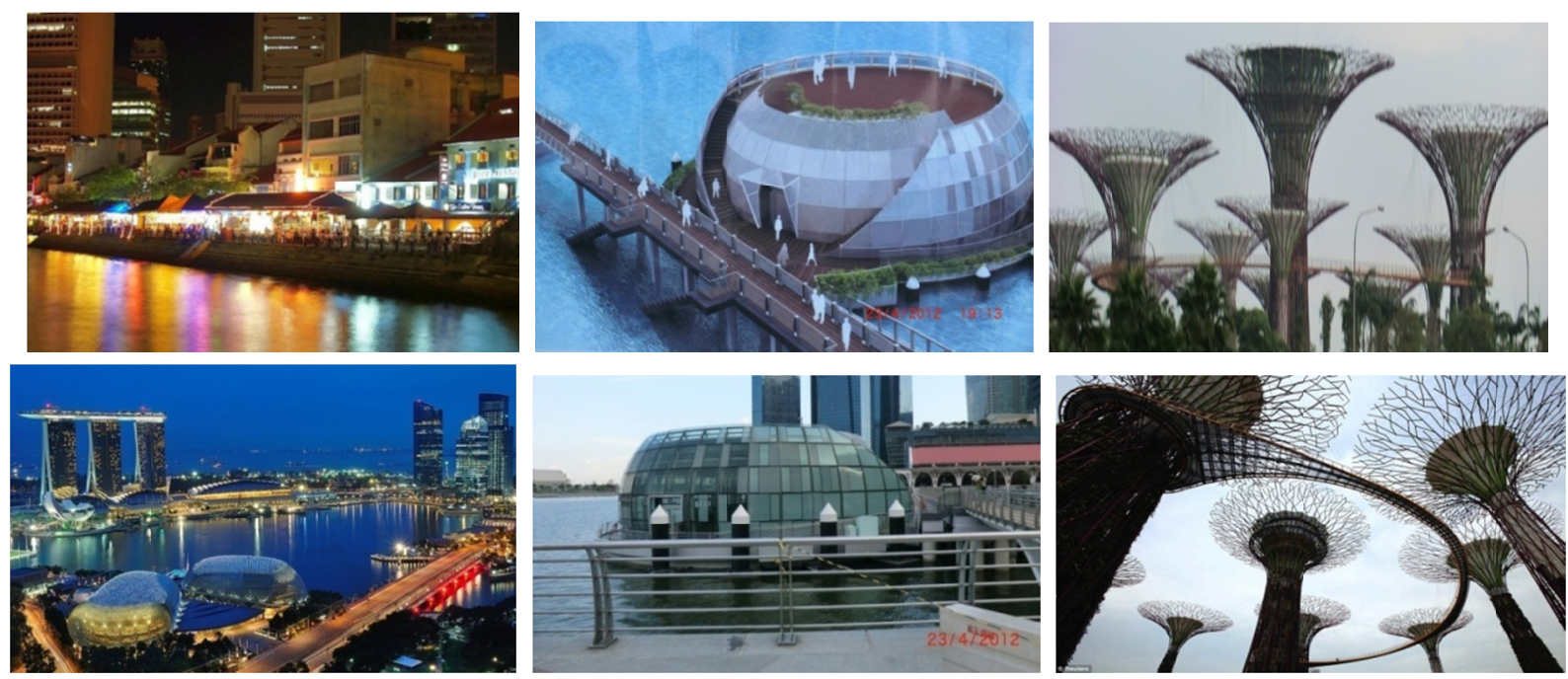

Figure 19. Singapore (left to right): Boat Quay, Marina Bay Promenade and Gardens by the Bay 


\section{Copyrights}

Copyright for this article is retained by the author(s), with first publication rights granted to the journal.

This is an open-access article distributed under the terms and conditions of the Creative Commons Attribution license (http://creativecommons.org/licenses/by/3.0/). 